\title{
LEVEL II SCOUR ANALYSIS FOR BRIDGE 50 (FFIETH00490050) on TOWN HIGHWAY 49, crossing BLACK CREEK, FAIRFIELD, VERMONT
}

Open-File Report 98-418

Prepared in cooperation with

VERMONT AGENCY OF TRANSPORTATION

and

FEDERAL HIGHWAY ADMINISTRATION

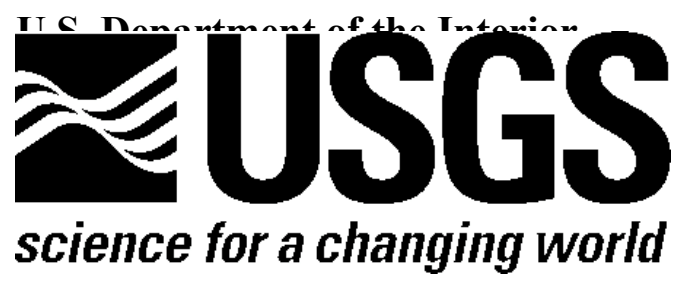




\section{LEVEL II SCOUR ANALYSIS FOR BRIDGE 50 (FFIETH00490050) on TOWN HIGHWAY 49, crossing BLACK CREEK, \\ FAIRFIELD, VERMONT \\ By SCOTT A. OLSON and LAURA MEDALIE}

U.S. Geological Survey Open-File Report 98-418

Prepared in cooperation with

VERMONT AGENCY OF TRANSPORTATION and

FEDERAL HIGHWAY ADMINISTRATION 


\title{
U.S. DEPARTMENT OF THE INTERIOR BRUCE BABBITT, Secretary
}

\author{
U.S. GEOLOGICAL SURVEY
}

Thomas J. Casadevall, Acting Director

For additional information write to:

District Chief

U.S. Geological Survey 361 Commerce Way

Pembroke, NH 03275-3718
Copies of this report may be purchased from:

U.S. Geological Survey

Branch of Information Services

Open-File Reports Unit

Box 25286

Denver, CO 80225-0286 


\section{CONTENTS}

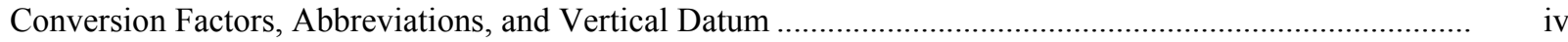

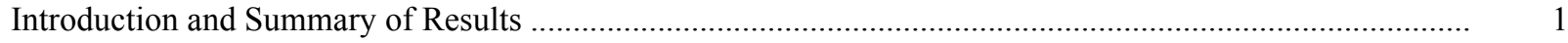

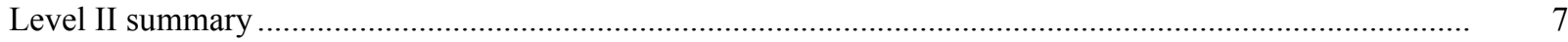

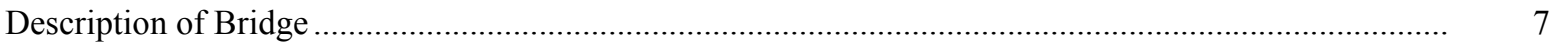

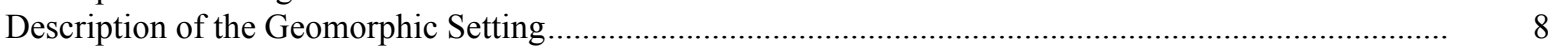

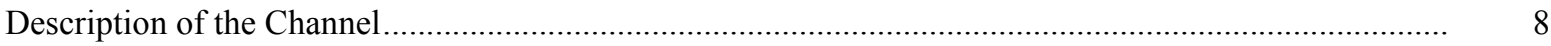

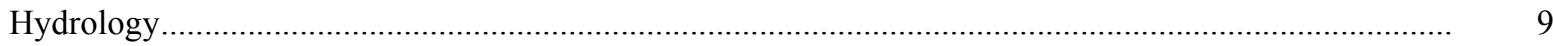

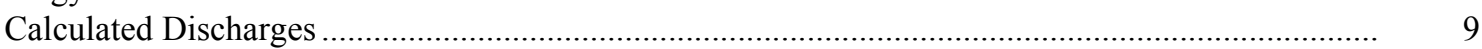

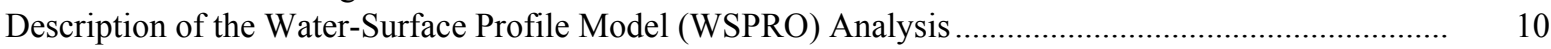

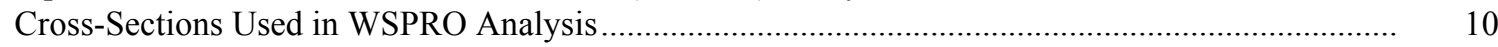

Data and Assumptions Used in WSPRO Model ........................................................................ 11

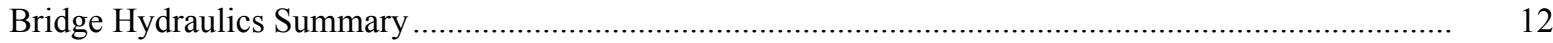

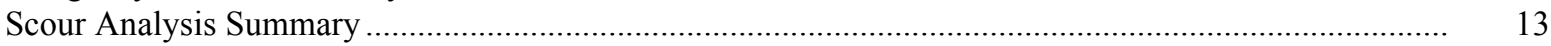

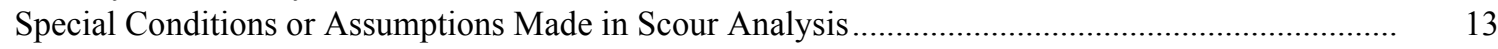

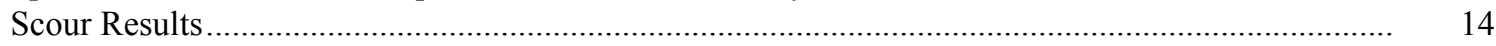

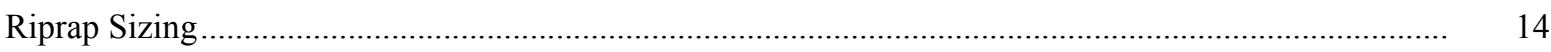

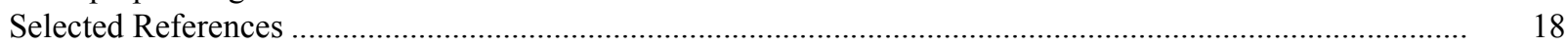

Appendices:

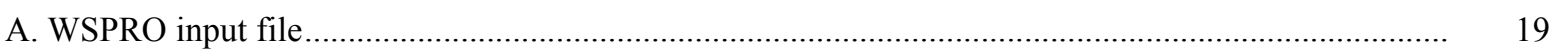

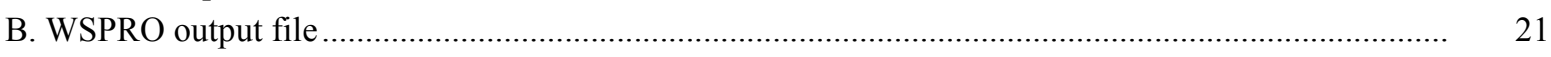

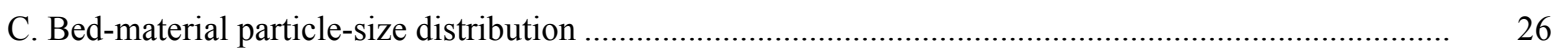

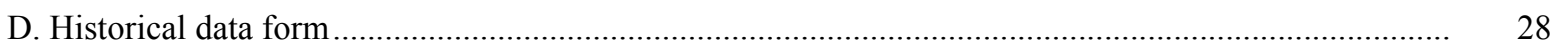

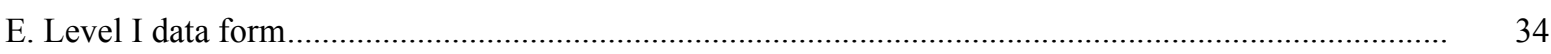

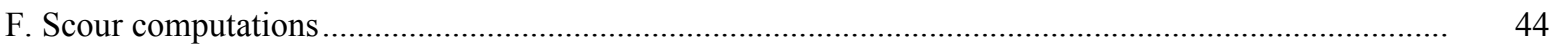

\section{FIGURES}

1. Map showing location of study area on USGS 1:24,000 scale map

2. Map showing location of study area on Vermont Agency of Transportation town highway map

3. Structure FFIETH00490050 viewed from upstream (July 12, 1995).

4. Downstream channel viewed from structure FFIETH00490050 (July 12, 1995) $\ldots \ldots \ldots \ldots \ldots$

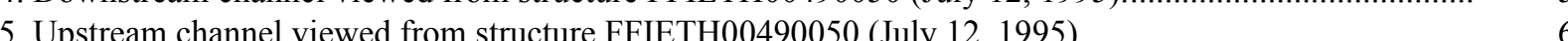

6. Structure FFIETH00490050 viewed from downstream (July 12, 1995).

7. Water-surface profiles for the 100- and 500-year discharges at structure FFIETH00490050 on Town Highway 49, crossing Black Creek, Fairfield, Vermont.

8. Scour elevations for the 100- and 500-year discharges at structure FFIETH00490050 on Town Highway 49, crossing Black Creek, Fairfield, Vermont.

\section{TABLES}

1. Remaining footing/pile depth at abutments for the 100-year discharge at structure FFIETH00490050 on Town Highway 49, crossing Black Creek, Fairfield, Vermont.

2. Remaining footing/pile depth at abutments for the 500-year discharge at structure FFIETH00490050 on Town Highway 49, crossing Black Creek, Fairfield, Vermont. 


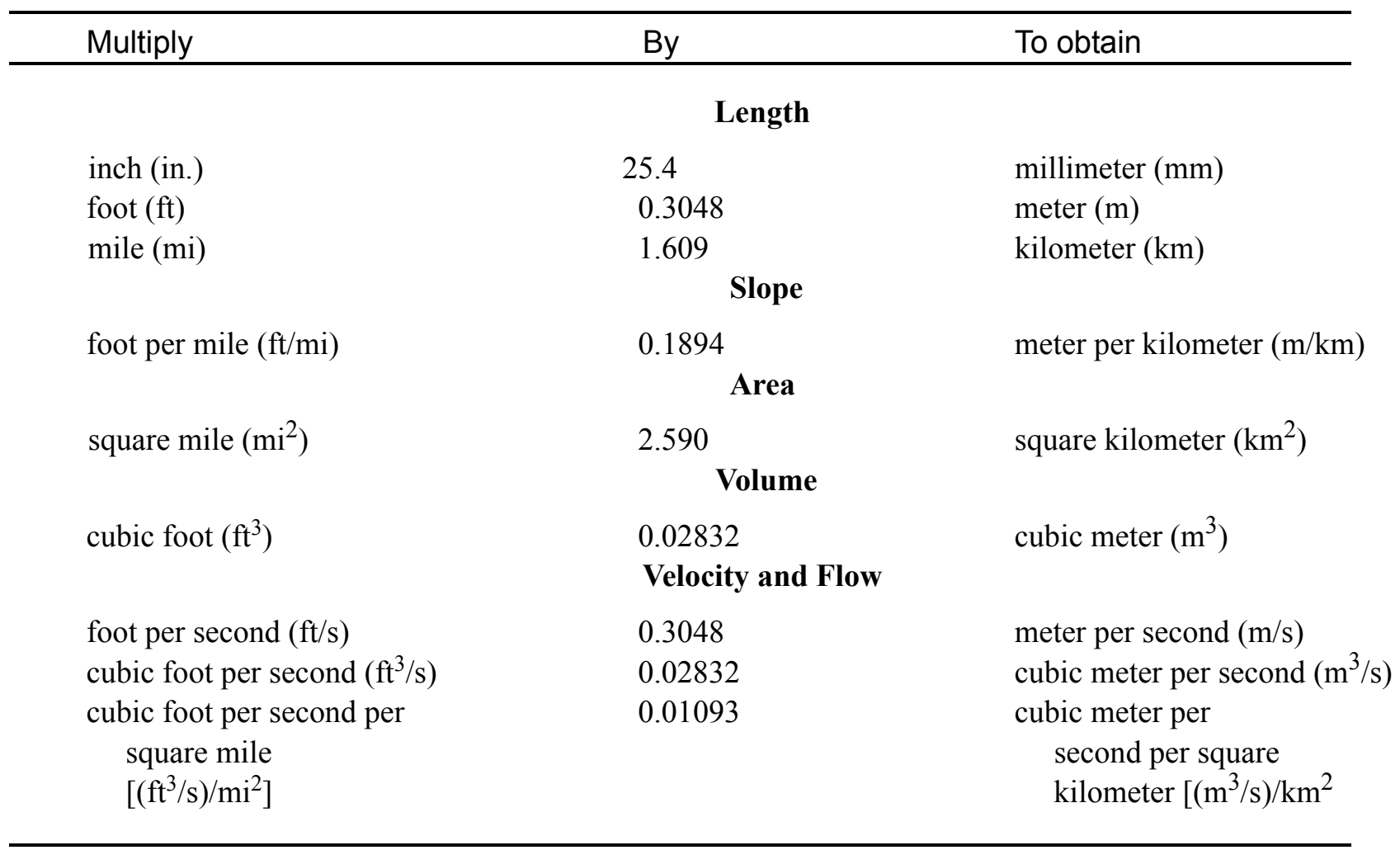

\section{OTHER ABBREVIATIONS}

$\begin{array}{lrlr}\mathrm{BF} & \text { bank full } & \text { LWW } & \text { left wingwall } \\ \mathrm{cfs} & \text { cubic feet per second } & \text { Max } & \text { maximum } \\ \mathrm{D}_{50} & \text { median diameter of bed material } & \text { MC } & \text { main channel } \\ \mathrm{DS} & \text { downstream } & \text { RAB } & \text { right abutment } \\ \mathrm{elev} & \text { elevation } & \text { RABUT } & \text { face of right abutment } \\ \mathrm{f} / \mathrm{p} & \text { flood plain } & \text { RB } & \text { right bank } \\ \mathrm{ft} & \text { square feet } & \text { ROB } & \text { right overbank } \\ \mathrm{ft} / \mathrm{ft} & \text { feet per foot } & \text { RWW } & \text { right wingwall } \\ \mathrm{FEMA} & \text { Federal Emergency Management Agency } & \text { TH } & \text { town highway } \\ \mathrm{FHWA} & \text { Federal Highway Administration } & \text { UB } & \text { under bridge } \\ \mathrm{JCT} & \text { junction } & \text { US } & \text { upstream } \\ \text { LAB } & \text { left abutment } & \text { USGS } & \text { United States Geological Survey } \\ \text { LABUT } & \text { face of left abutment } & \text { VTAOT } & \text { Vermont Agency of Transportation } \\ \text { LB } & \text { left bank } & \text { WSPRO } & \text { water-surface profile model } \\ \text { LOB } & \text { left overbank } & \text { yr } & \text { year }\end{array}$

In this report, the words "right" and "left" refer to directions that would be reported by an observer facing downstream. Sea level: In this report, "sea level" refers to the National Geodetic Vertical Datum of 1929-- a geodetic datum derived from a general adjustment of the first-order level nets of the United States and Canada, formerly called Sea Level Datum of 1929.

In the appendices, the above abbreviations may be combined. For example, USLB would represent upstream left bank. 


\title{
LEVEL II SCOUR ANALYSIS FOR BRIDGE 50 (FFIETH00490050) ON TOWN HIGHWAY 49, CROSSING BLACK CREEK, FAIRFIELD, VERMONT
}

\author{
By Scott A. Olson and Laura Medalie
}

\section{INTRODUCTION AND SUMMARY OF RESULTS}

This report provides the results of a detailed Level II analysis of scour potential at structure FFIETH00490050 on Town Highway 49 crossing Black Creek, Fairfield, Vermont (figures 1-8). A Level II study is a basic engineering analysis of the site, including a quantitative analysis of stream stability and scour (FHWA, 1993). Results of a Level I scour investigation also are included in appendix $\mathrm{E}$ of this report. A Level I investigation provides a qualitative geomorphic characterization of the study site. Information on the bridge, gleaned from Vermont Agency of Transportation (VTAOT) files, was compiled prior to conducting Level I and Level II analyses and is found in appendix D.

The site is in the Green Mountain section of the New England physiographic province in northwestern Vermont. The $35.1-\mathrm{mi}^{2}$ drainage area is in a predominantly rural and forested basin. In the vicinity of the study site, the surface cover is lawn except the downstream left overbank, which is brush and some trees.

In the study area, Black Creek has an incised, sinuous channel with an average channel top width of $66 \mathrm{ft}$ and an average bank height of $6 \mathrm{ft}$. Approximately $235 \mathrm{ft}$ downstream of the bridge is an old mill dam, which backs water up through the bridge. The channel bed material ranges from silt to boulders with bedrock outcrops. The median grain size $\left(D_{50}\right)$ is $0.079 \mathrm{~mm}(0.00026 \mathrm{ft})$. The geomorphic assessment at the time of the Level I and Level II site visit on July 12,1995 , indicated that the reach was stable.

The Town Highway 49 crossing of Black Creek is a 70-ft-long, one-lane covered bridge consisting of one 59-foot wooden span (Vermont Agency of Transportation, written communication, March 09, 1995). The opening length of the structure parallel to the bridge face is $58.6 \mathrm{ft}$. The bridge is supported by vertical, stone abutments. The right abutment is partially faced with concrete. The channel is skewed approximately 10 degrees to the opening while the opening-skew-to-roadway is 0 degrees. The bridge has been closed to traffic since January 1987. 
Approximately $1 \mathrm{ft}$ of scour deeper than the mean thalweg depth was observed along the upstream end of the right abutment during the Level I assessment. Scour countermeasures at the site included type-1 stone fill (less than 12 inches diameter) sparsely distributed along the downstream left wingwall, type-2 stone fill (less than 36 inches diameter) located at the upstream end of the upstream left wingwall and sporadically along the right abutment, and a wooden retaining wall located along the downstream right bank. Additional details describing conditions at the site are included in the Level II Summary and appendices D and E.

Scour depths and recommended rock rip-rap sizes were computed using the general guidelines described in Hydraulic Engineering Circular 18 (Richardson and Davis, 1995) for the 100- and 500-year discharges. Total scour at a highway crossing is comprised of three components: 1) long-term streambed degradation; 2) contraction scour (due to accelerated flow caused by a reduction in flow area at a bridge) and; 3 ) local scour (caused by accelerated flow around piers and abutments). Total scour is the sum of the three components. Equations are available to compute depths for contraction and local scour and a summary of the results of these computations follows.

Contraction scour for all modelled flows ranged from 0.4 to $3.1 \mathrm{ft}$. The worst-case contraction scour occurred at the 500-year discharge. Abutment scour ranged from 7.9 to $11.1 \mathrm{ft}$ at the left abutment and 12.6 to 16.6 at the right abutment. The worst-case abutment scour occurred at the 500-year discharge. Additional information on scour depths and depths to armoring are included in the section titled "Scour Results". Bedrock was observed at the right abutment and may limit the amount of scour that will occur at this site. Scoured-streambed elevations, based on the calculated scour depths, are presented in tables 1 and 2. A cross-section of the scour computed at the bridge is presented in figure 8. Scour depths were calculated assuming an infinite depth of erosive material and a homogeneous particle-size distribution.

It is generally accepted that the Froehlich equation (abutment scour) gives "excessively conservative estimates of scour depths" (Richardson and Davis, 1995, p. 46). Usually, computed scour depths are evaluated in combination with other information including (but not limited to) historical performance during flood events, the geomorphic stability assessment, existing scour protection measures, and the results of the hydraulic analyses. Therefore, scour depths adopted by VTAOT may differ from the computed values documented herein. 


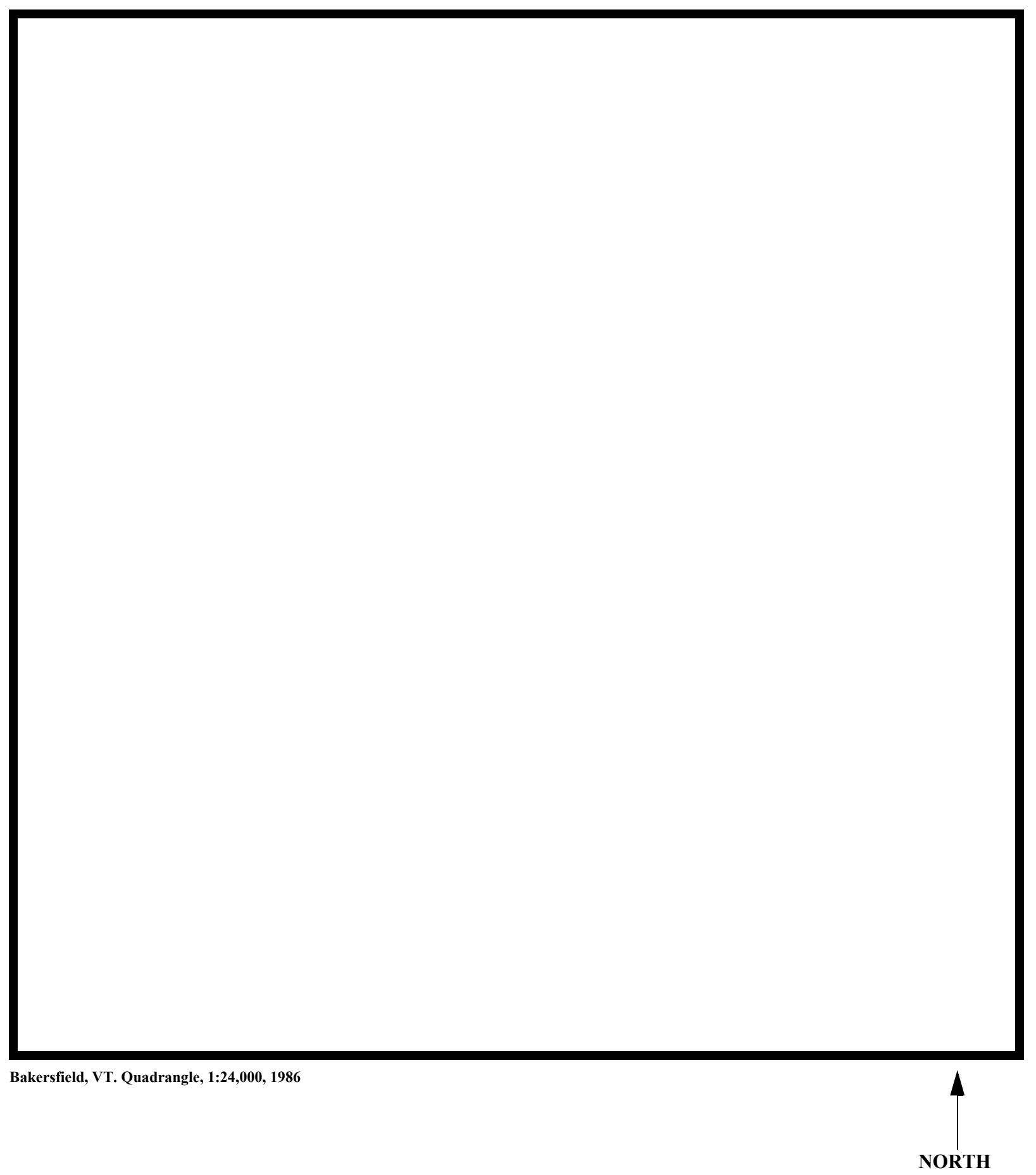

Figure 1. Location of study area on USGS 1:24,000 scale map. 
Figure 2. Location of study area on Vermont Agency of Transportation town highway map. 

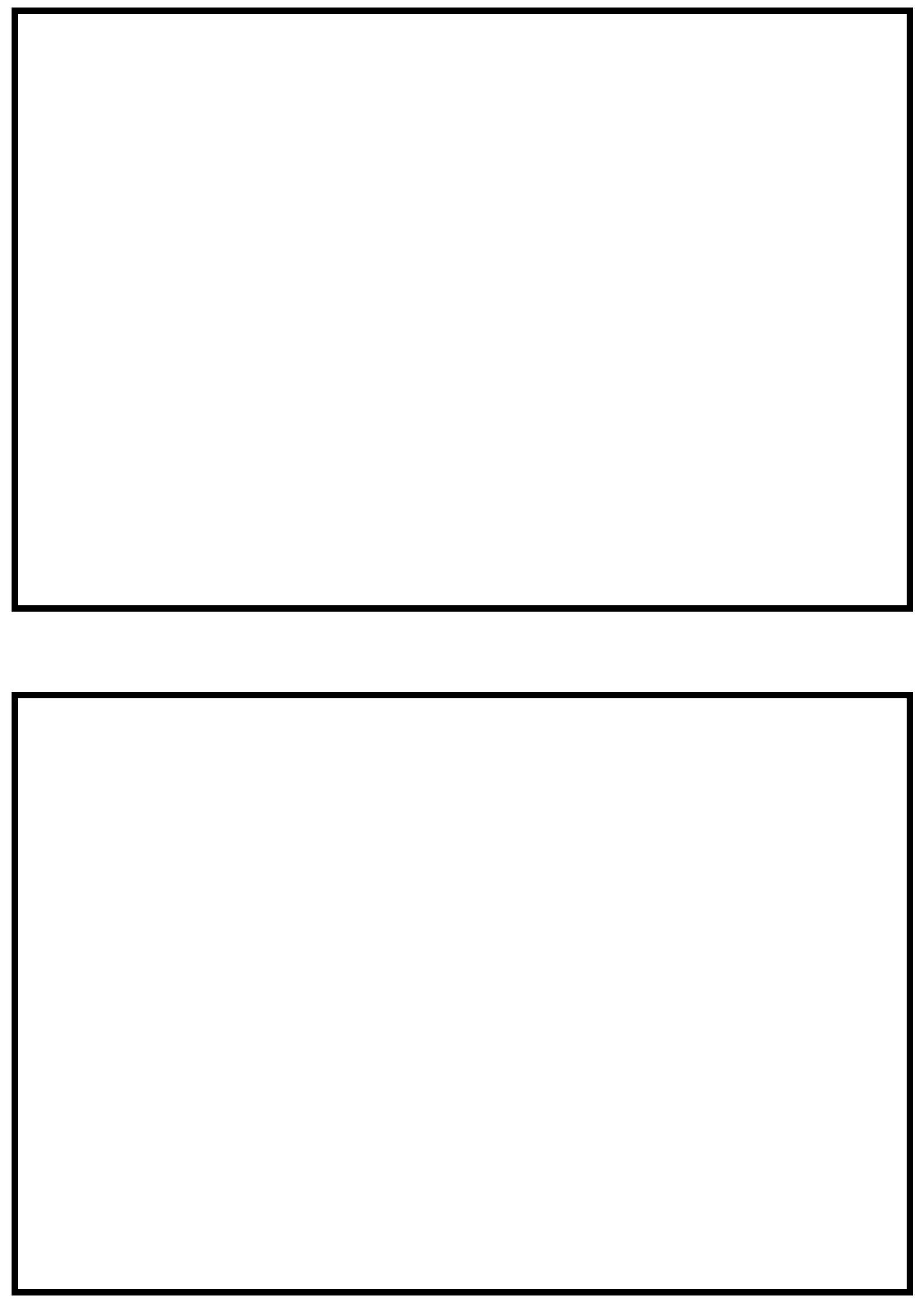

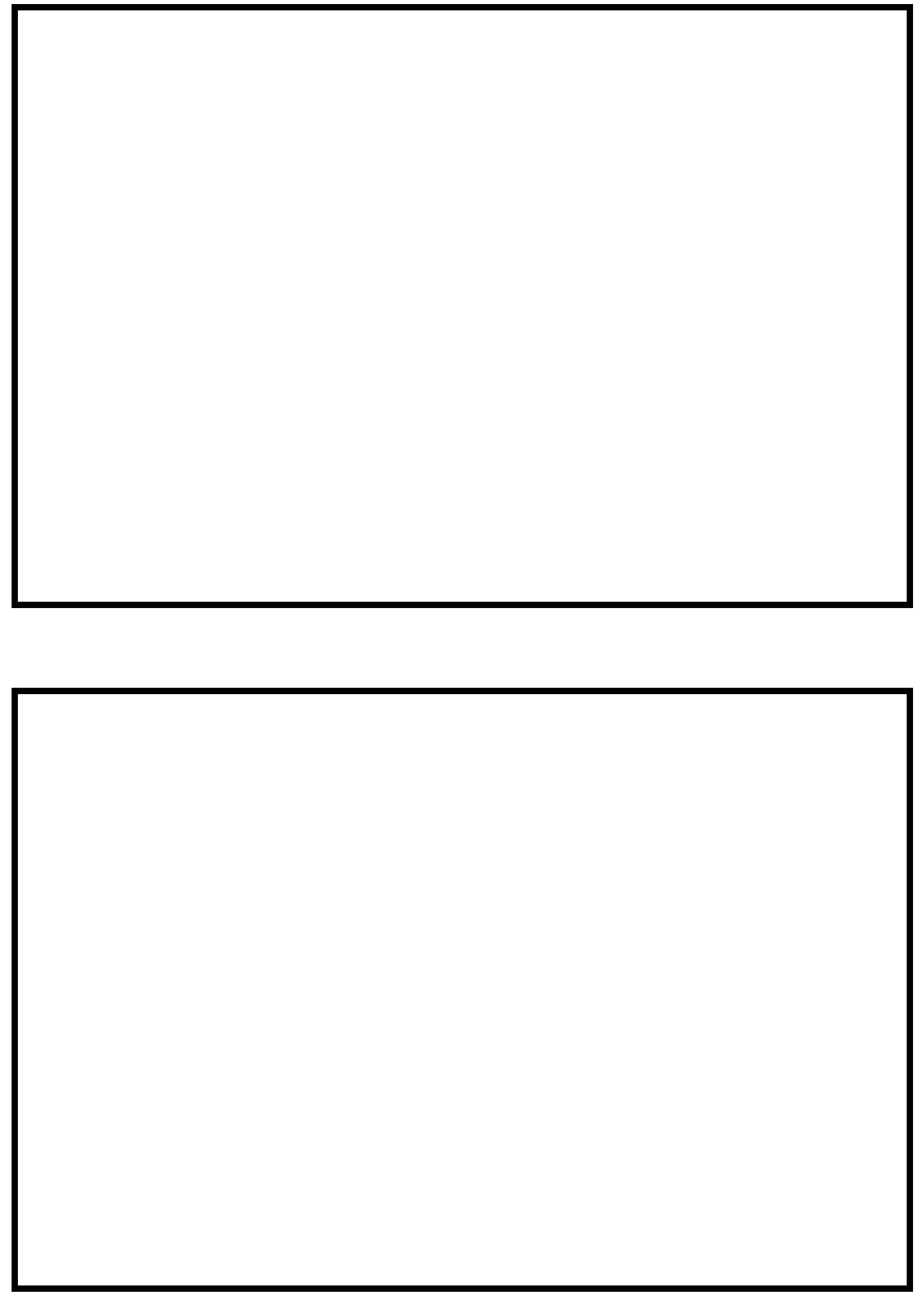


\section{LEVEL II SUMMARY}

\begin{tabular}{llllll} 
Structure Number & FFIETH00490050 & Stream & \multicolumn{3}{c}{ Black Creek } \\
& Road & TH 49 & District & 8
\end{tabular}

\section{Description of Bridge}

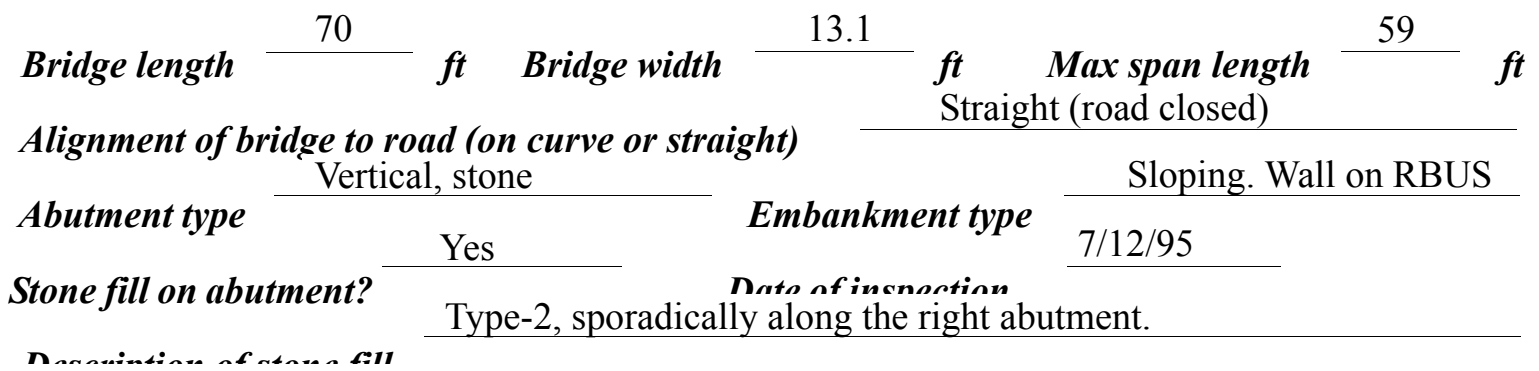

Abutments are stone. The upstream half of the right

abutment has been faced with concrete. Much of the exposed stone have deep gaps between

stones. On the left abutment most of the gaps have been filled with concrete.

Yes

Is bridge skewed to flood flow according to Yes ' survey?

Angle

There is a moderate channel bend in the downstream, reach

Debris accumulation on bridge at time of Level I or Level II site visit:

\begin{tabular}{|c|c|c|c|}
\hline & $\begin{array}{c}\text { Date of insmortion } \\
\underline{7 / 12 / 95} \\
\end{array}$ & $\begin{array}{l}\text { Percent of almmust } \\
\text { blocked inortzontatly }\end{array}$ & $\begin{array}{l}\text { Percent of } 0 \\
\text { blocked verticatty }\end{array}$ \\
\hline & $7 / 12 / 95$ & 0 & 0 \\
\hline & Low. & & \\
\hline
\end{tabular}

Potential for debris

There is a dam $235 \mathrm{ft}$ downstream of the bridge, which backs water up through the structure. Doscriho anv, foaturos noar ar at tho hridos that mav, affoct flou, (includo ahsorvation dato) 


\section{Description of the Geomorphic Setting}

General topography The channel is located within a moderate relief valley. There are bedrock falls both upstream and downstream of the bridge.

Geomorphic conditions at bridge site: downstream (DS), upstream (US)

Date of inspection $\quad 7 / 12 / 95$

DS left: $\quad$ Moderately sloping bank and irregular overbank.

DS right: Channel boundary is bedrock with a mildly sloping overbank.

US left: $\quad$ Mildly sloping bank and overbank.

US right: $\quad$ Mildly sloping bank and overbank.

\section{Description of the Channel}

\begin{tabular}{|c|c|c|c|}
\hline \multirow[b]{2}{*}{ Average top width } & 66 & \multirow[b]{2}{*}{ Average depth } & \multirow[b]{2}{*}{ Sand with boulder } \\
\hline & $\begin{array}{c}\boldsymbol{f} \\
\text { Silt with boulders }\end{array}$ & & \\
\hline redominant bec & & Bank material & Sinuous but stable \\
\hline
\end{tabular}

With semi-allúvial to non-alluvial channel boundaries and a narrow flood plain.

Vegetative co 1 Brush with trees.

DS left: $\quad$ Lawn.

DS right: Lawn with a narrow strip of brush on the immediate bank.

US left: Lawn.

US right: $\quad$ Yes

Do banks appear stable? -

date of observatton.

None. July 12, 1995.

Describe any obstructions in channel and date of observation. 


\title{
Hydrology
}

Drainage area $\stackrel{35.1}{ } \boldsymbol{m i}^{2}$

Percentage of drainage area in physiographic provinces: (approximate)

Physiographic province/section

New England/Green Mountain
Percent of drainage area 100

\begin{abstract}
Is drainage area considered rural or urban?
Rural None. urbanization:西

Describe any significant
\end{abstract}

Is there a USGS gage on the stream of interest?

No

USGS gage description

USGS gage number

Gage drainage area $\mathrm{mi}^{2}$

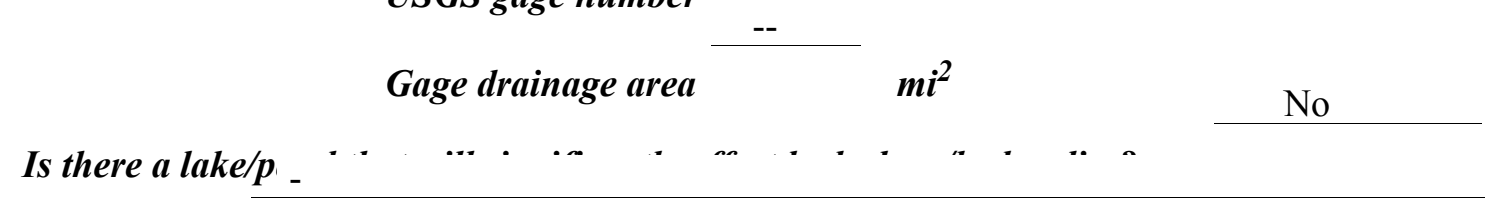

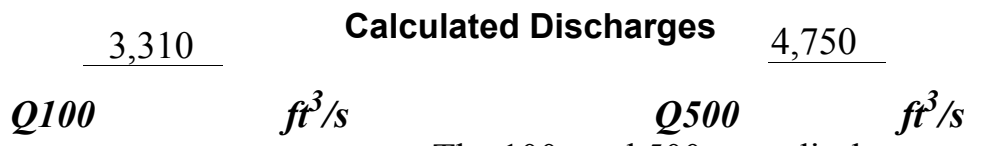

The 100- and 500-year discharges are based on a

drainage area relationship [(35.1/46.7)exp 0.67] with flood frequency estimates available from the VAOT database (written communication, May 1995) for bridge number 9 in Fairfield. Bridge number 9 crosses Black Creek downstream of this site and has a drainage area of 46.7 square miles. The values used were within a range defined by flood frequency curves developed from several empirical methods (Benson, 1962; Johnson and Tasker, 1974; FHWA, 1983; Potter, $1957 \mathrm{a} \& \mathrm{~b} ;$ Talbot, 1887). Each curve was extended graphically to the 500 -year event. 


\section{Description of the Water-Surface Profile Model (WSPRO) Analysis}

Datum for WSPRO analysis (USGS survey, sea level, VTAOT plans)

USGS survey

Datum tie between USGS survey and VTAOT plans

None

Description of reference marks used to determine USGS datum. $\quad$ RM1 is a chiseled X on top of the upstream end of the right abutment (elev. $499.91 \mathrm{ft}$, arbitrary survey datum). RM2 is a chiseled X on top of the downstream end of the left abutment (elev. $498.17 \mathrm{ft}$, arbitrary survey

datum). RM4 is a chiseled $\mathrm{X}$ on a bedrock outcrop, $3 \mathrm{ft}$ from the right side of the dam (elev.

$495.74 \mathrm{ft}$, arbitrary survey datum).

\section{Cross-Sections Used in WSPRO Analysis}

\begin{tabular}{cccl}
\hline${ }^{1}$ Cross-section & $\begin{array}{c}\text { Section } \\
\text { Reference } \\
\text { Distance } \\
(\text { SRD) } \text { in feet }\end{array}$ & $\begin{array}{c}{ }^{2} \text { Cross-section } \\
\text { development }\end{array}$ & \multicolumn{1}{c}{ Comments } \\
\hline DAM & -235 & 1 & Section across dam \\
EXITX & -89 & 1 & $\begin{array}{l}\text { Exit Section } \\
\text { Downstream Full-valley } \\
\text { section (Templated from } \\
\text { FULLV }\end{array}$ \\
BRIDG & 0 & 2 & $\begin{array}{l}\text { EXITX) } \\
\text { Bridge section }\end{array}$ \\
RDWAY & 0 & 1 & $\begin{array}{l}\text { Road Grade section } \\
\text { Modelled Approach sec- } \\
\text { tion (Templated from }\end{array}$ \\
APPRO & 9 & 1 & $\begin{array}{l}\text { APTEM) } \\
\text { Approach section as sur- } \\
\text { veyed (Used as a tem- }\end{array}$ \\
\hline
\end{tabular}

${ }^{1}$ For location of cross-sections see plan-view sketch included with Level I field form, appendix E. For more detail on how cross-sections were developed see WSPRO input file. 


\section{Data and Assumptions Used in WSPRO Model}

Hydraulic analyses of the reach were done by use of the Federal Highway Administration's WSPRO step-backwater computer program (Shearman and others, 1986, and Shearman, 1990). The analyses reported herein reflect conditions existing at the site at the time of the study. Furthermore, in the development of the model it was necessary to assume no accumulation of debris or ice at the site. Results of the hydraulic model are presented in the Bridge Hydraulic Summary, appendix B, and figure 7.

Channel roughness factors (Manning's " $n$ ") used in the hydraulic model were estimated using field inspections at each cross section following the general guidelines described by Arcement and Schneider (1989). Final adjustments to the values were made during the modelling of the reach. Channel " $n$ " values for the reach ranged from 0.025 to 0.038 , and overbank " $n$ " values ranged from 0.035 to 0.075 .

Critical depth at the dam section (DAM) was assumed as the starting water surface.

Critical depth was allowed because it was determined that normal depth immediately downstream of the dam did not submerge the dam. Normal depth was computed in a section surveyed downstream of the dam by use of the slope-conveyance method outlined in the user's manual for WSPRO (Shearman, 1990). The slope used was $0.00056 \mathrm{ft} / \mathrm{ft}$, which was estimated from the topographic map (U.S. Geological Survey, 1986).

The surveyed approach section (APTEM) was moved to establish the modelled approach section (APPRO), one bridge length upstream of the upstream face as recommended by Shearman and others (1986). This location provides a consistent method for determining scour variables. 


\section{Bridge Hydraulics Summary}

$\begin{array}{llll}\text { Average bridge embankment elevation } & 500.2 & f t \\ \text { Average low steel elevation } & 498.1 & \boldsymbol{f t}\end{array}$

100-year discharge $\quad 3,310 \quad \mathrm{ft}^{3} / \mathrm{s}$

Water-surface elevation in bridge opening $\quad 497.3$ ft

Road overtopping? ___ No Discharge over road ___ -- $\mathrm{ft}^{3} / \mathrm{s}$

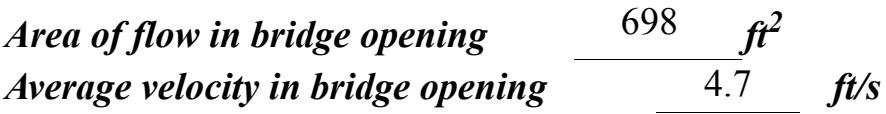

Maximum WSPRO tube velocity at bridge $\quad 5.9 \mathrm{ft} / \mathrm{s}$

Water-surface elevation at Approach section with bridge 497.6

Water-surface elevation at Approach section without bridge $\quad \overline{497.6}$

Amount of backwater caused by bridge $\quad 0.0 \quad$ it

500-year discharge $\quad 4,750 \quad \mathrm{ft}^{3} / \mathrm{s}$

Water-surface elevation in bridge opening $\quad 498.6 \mathrm{ft}$

Road overtopping? ___ No Discharge over road ___ $f^{3} / \mathrm{s}$

Area of flow in bridge opening _ $\quad 732 \quad \mathrm{ft}^{2}$

Average velocity in bridge opening $6.5 \mathrm{ft} / \mathrm{s}$

Maximum WSPRO tube velocity at bridge 7.7 , s

Water-surface elevation at Approach section with bridge 499.4

Water-surface elevation at Approach section without bridge $\quad 499.0$

Amount of backwater caused by bridge 0.4 .

Incipient overtopping discharge ___ -- $f^{3} / \mathrm{s}$

Water-surface elevation in bridge opening $\quad--\quad t$

Area of flow in bridge opening _ $\quad--\quad \mathrm{ft}^{2}$

Average velocity in bridge opening $\quad--\quad f t / s$

Maximum WSPRO tube velocity at bridge $\quad--\quad f t / s$

Water-surface elevation at Approach section with bridge

Water-surface elevation at Approach section without bridge

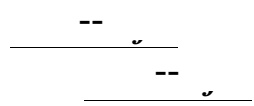

Amount of backwater caused by bridge _ 


\section{Scour Analysis Summary}

\section{Special Conditions or Assumptions Made in Scour Analysis}

Scour depths were computed using the general guidelines described in Hydraulic Engineering Circular 18 (Richardson and Davis, 1995). Scour depths were calculated assuming an infinite depth of erosive material and a homogeneous particle-size distribution. The results of the scour analyses for the 100- and 500-year discharges are presented in tables 1 and 2 and the scour depths are shown graphically in figure 8 .

Contraction scour was computed by use of the Laursen live-bed contraction scour equation (Richardson and Davis, 1995, p. 30, equation 17). At this site, the 500-year discharge resulted in submerged orifice flow. Typically, contraction scour at bridges with orifice flow is best estimated by use of the Chang pressure-flow scour equation (oral communication, J. Sterling Jones, October 4, 1996). The result of Chang's contraction scour equation (Richardson and others, 1995, p. 145-146) for this event was also computed and can be found in appendix F. Because the Chang equation for pressure flow scour was derived solely with data for clear-water scour, it is not currently understood how well it would predict in live-bed conditions. Therefore, although pressure flow conditions exist for the 500-year discharge, the reported scour depths were computed using Laursen's live-bed contraction scour equation.

Abutment scour was computed by use of the Froehlich equation (Richardson and Davis, 1995, p. 48, equation 28). Variables for the Froehlich equation include the Froude number of the flow approaching the embankments, the length of the embankment blocking flow, and the depth of flow approaching the embankment less any roadway overtopping. 


\section{Scour Results}

Contraction scour:

Main channel

Live-bed scour

Clear-water scour

Depth to armoring

Left overbank

Right overbank

Local scour:

Abutment scour

Left abutment

Right abutment

Pier scour

Pier 1

Pier 2

Pier 3
7.9

$12.6-$
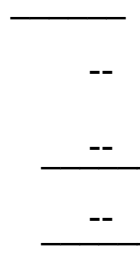

Incipient

500-year overtopping discharge discharge

(Scour depths in feet)
0.4

$--$

N/A

$-$

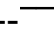

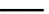

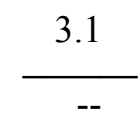

N/A

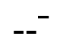

$--$

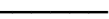




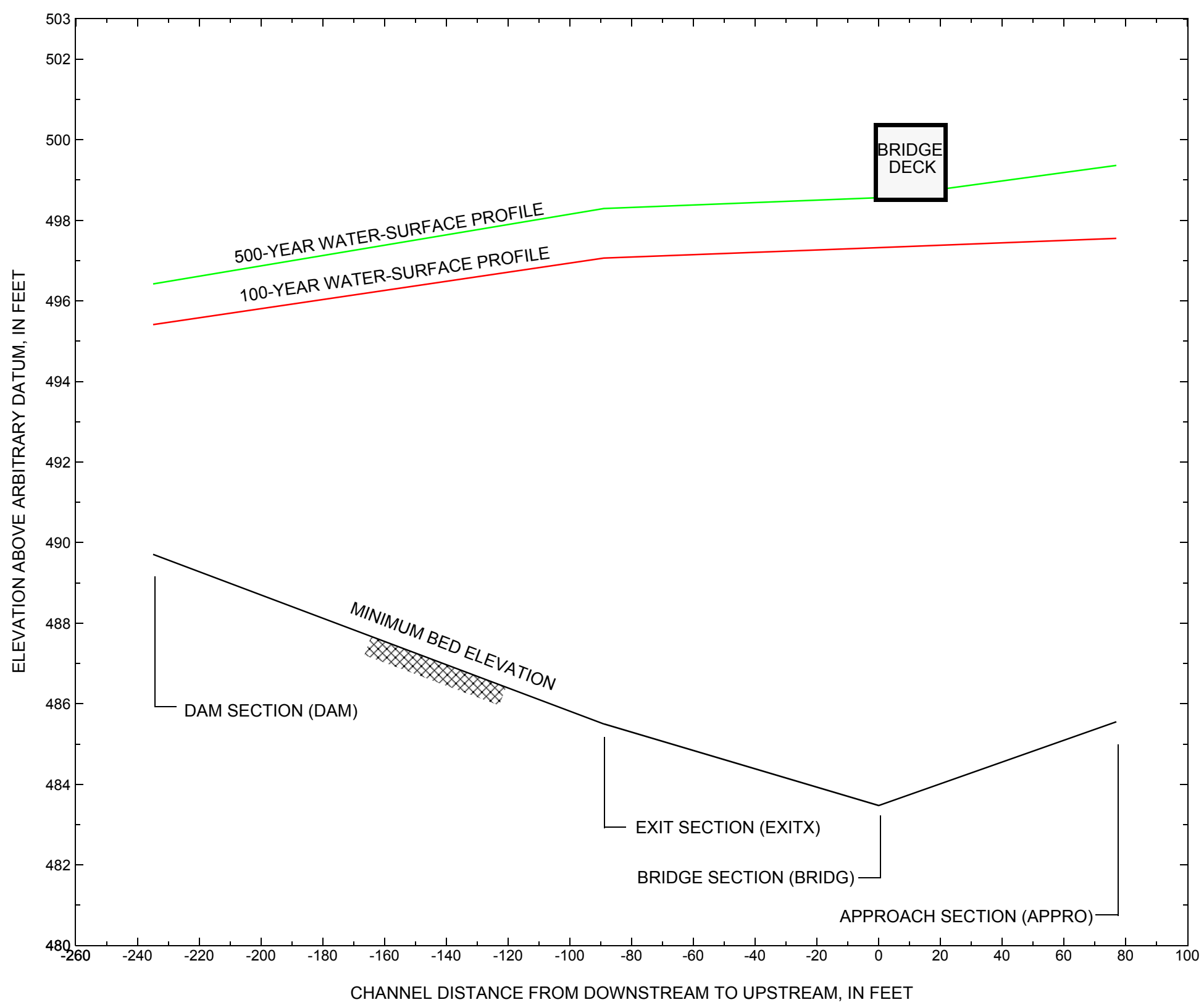

Figure 7. Water-surface profiles for the 100- and 500-year discharges at structure FFIETH00490050 on Town Highway 49, crossing Black Creek, Fairfield, Vermont. 


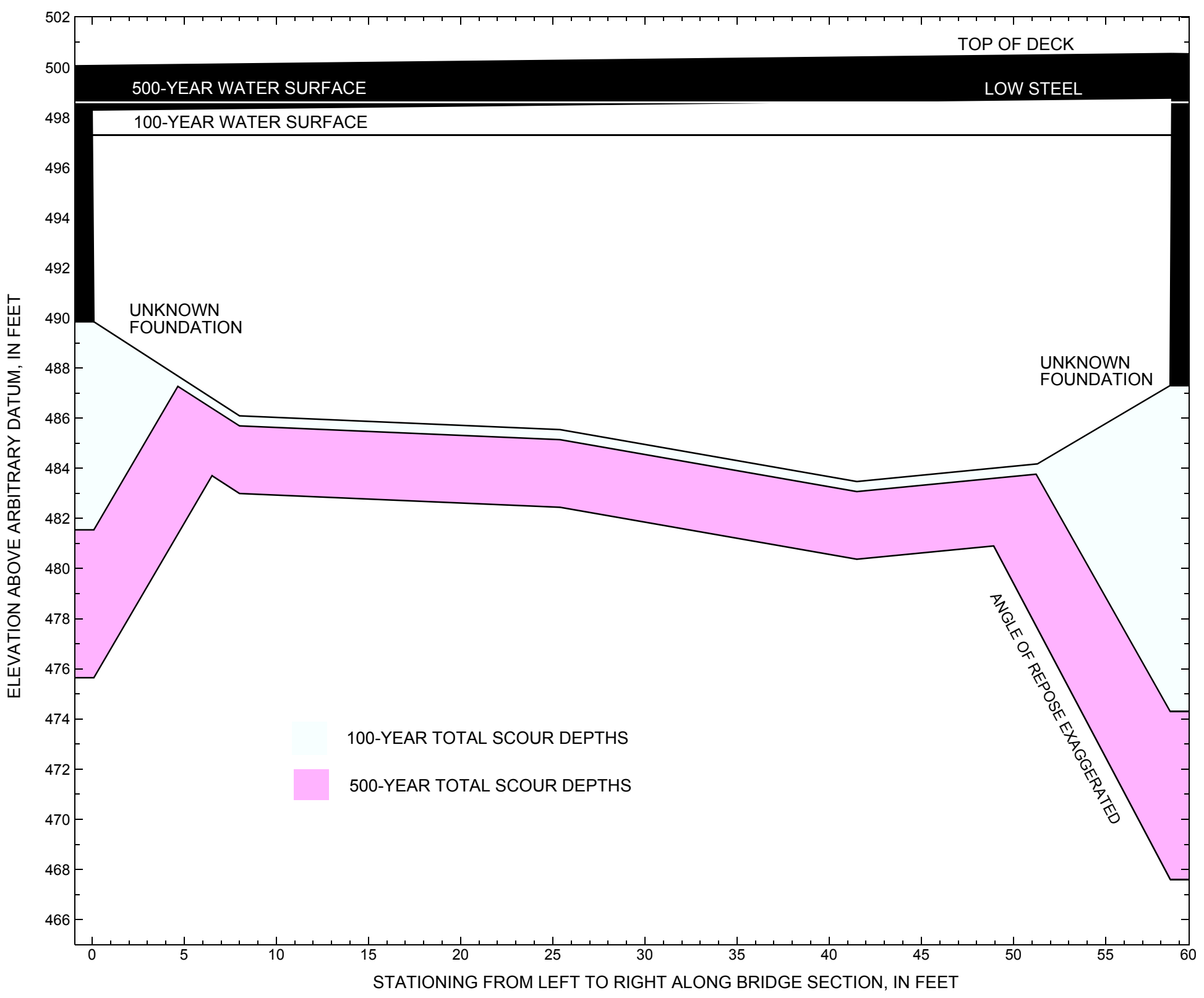

Figure 8. Scour elevations for the 100- and 500-year discharges at structure FFIETH00490050 on Town Highway 49, crossing Black Creek, Fairfield, Vermont. 


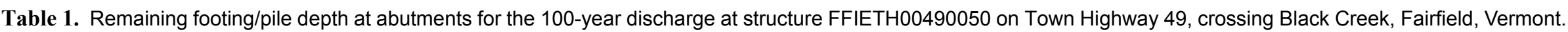
[VTAOT, Vermont Agency of Transportation; --, no data]

\begin{tabular}{|c|c|c|c|c|c|c|c|c|c|c|c|}
\hline Description & Station $^{1}$ & $\begin{array}{l}\text { VTAOT } \\
\text { minimum } \\
\text { low-chord } \\
\text { elevation } \\
\text { (feet) }\end{array}$ & $\begin{array}{c}\text { Surveyed } \\
\text { minimum } \\
\text { low-chord } \\
\text { elevation } \\
\text { (feet) }\end{array}$ & $\begin{array}{c}\text { Bottom of } \\
\text { footing/pile } \\
\text { elevation } \\
\text { (feet) }\end{array}$ & $\begin{array}{c}\text { Channel } \\
\text { elevation at } \\
\text { abutment/ } \\
\text { pier }^{2} \\
\text { (feet) }\end{array}$ & $\begin{array}{l}\text { Contraction } \\
\text { scour depth } \\
\text { (feet) }\end{array}$ & $\begin{array}{l}\text { Abutment } \\
\text { scour } \\
\text { depth } \\
\text { (feet) }\end{array}$ & $\begin{array}{l}\text { Pier } \\
\text { scour } \\
\text { depth } \\
\text { (feet) }\end{array}$ & $\begin{array}{l}\text { Depth of } \\
\text { total scour } \\
\text { (feet) }\end{array}$ & $\begin{array}{c}\text { Elevation of } \\
\text { scour }^{2} \\
\text { (feet) }\end{array}$ & $\begin{array}{c}\text { Remaining } \\
\text { footing/pile } \\
\text { depth } \\
\text { (feet) }\end{array}$ \\
\hline \multicolumn{12}{|c|}{100 -year discharge is 3,310 cubic-feet per second } \\
\hline Left abutment & 0.0 & -- & 498.3 & -- & 489.8 & 0.4 & 7.9 & -- & 8.3 & 481.5 & -- \\
\hline Right abutment & 58.6 & -- & 498.8 & -- & 487.3 & 0.4 & 12.6 & -- & 13.0 & 474.3 & -- \\
\hline
\end{tabular}

1.Measured along the face of the most constricting side of the bridge.

2.Arbitrary datum for this study.

Table 2. Remaining footing/pile depth at abutments for the 500-year discharge at structure FFIETH00490050 on Town Highway 49, crossing Black Creek, Fairfield, Vermont. [VTAOT, Vermont Agency of Transportation; --, no data]

\begin{tabular}{|c|c|c|c|c|c|c|c|c|c|c|c|}
\hline Description & Station $^{1}$ & $\begin{array}{l}\text { VTAOT } \\
\text { minimum } \\
\text { low-chord } \\
\text { elevation } \\
\text { (feet) }\end{array}$ & $\begin{array}{l}\text { Surveyed } \\
\text { minimum } \\
\text { low-chord } \\
\text { elevation } \\
\text { (feet) }\end{array}$ & $\begin{array}{c}\text { Bottom of } \\
\text { footing/pile } \\
\text { elevation }{ }^{2} \\
\text { (feet) }\end{array}$ & $\begin{array}{c}\text { Channel } \\
\text { elevation at } \\
\text { abutment/ } \\
\text { pier }^{2} \\
\text { (feet) }\end{array}$ & $\begin{array}{l}\text { Contraction } \\
\text { scour depth } \\
\text { (feet) }\end{array}$ & $\begin{array}{l}\text { Abutment } \\
\text { scour } \\
\text { depth } \\
\text { (feet) }\end{array}$ & $\begin{array}{l}\text { Pier } \\
\text { scour } \\
\text { depth } \\
\text { (feet) }\end{array}$ & $\begin{array}{l}\text { Depth of } \\
\text { total scour } \\
\text { (feet) }\end{array}$ & $\begin{array}{c}\text { Elevation of } \\
\text { scour }^{2} \\
\text { (feet) }\end{array}$ & $\begin{array}{c}\text { Remaining } \\
\text { footing/pile } \\
\text { depth } \\
\text { (feet) }\end{array}$ \\
\hline \multicolumn{12}{|c|}{500 -year discharge is 4,750 cubic-feet per second } \\
\hline Left abutment & 0.0 & -- & 498.3 & -- & 489.8 & 3.1 & 11.1 & -- & 14.2 & 475.6 & -- \\
\hline Right abutment & 58.6 & -- & 498.8 & -- & 487.3 & 3.1 & 16.6 & -- & 19.7 & 467.6 & -- \\
\hline
\end{tabular}

1.Measured along the face of the most constricting side of the bridge.

2.Arbitrary datum for this study. 


\section{SELECTED REFERENCES}

Arcement, G.J., Jr., and Schneider, V.R., 1989, Guide for selecting Manning's roughness coefficients for natural channels and flood plains: U.S. Geological Survey Water-Supply Paper 2339, 38 p.

Barnes, H.H., Jr., 1967, Roughness characteristics of natural channels: U.S. Geological Survey Water-Supply Paper 1849,213 p.

Benson, M. A., 1962, Factors Influencing the Occurrence of Floods in a Humid Region of Diverse Terrain: U.S. Geological Survey WaterSupply Paper 1580-B, 64 p.

Brown, S.A. and Clyde, E.S., 1989, Design of riprap revetment: Federal Highway Administration Hydraulic Engineering Circular No. 11, Publication FHWA-IP-89-016, 156 p.

Federal Highway Administration, 1983, Runoff estimates for small watersheds and development of sound design: Federal Highway Administration Report FHWA-RD-77-158.

Federal Highway Administration, 1993, Stream Stability and Scour at Highway Bridges: Participant Workbook: Federal Highway Administration Report FHWA-HI-91-011.

Froehlich, D.C., 1989, Local scour at bridge abutments in Ports, M.A., ed., Hydraulic Engineering--Proceedings of the 1989 National Conference on Hydraulic Engineering: New York, American Society of Civil Engineers, p. 13-18.

Hayes, D.C.,1993, Site selection and collection of bridge-scour data in Delaware, Maryland, and Virginia: U.S. Geological Survey WaterResources Investigation Report 93-4017, 23 p.

Interagency Advisory Committee on Water Data, 1982, Guidelines for determining flood flow frequency: U.S. Geological Survey, Bulletin 17B of the Hydrology Subcommittee, 190 p.

Johnson, C.G. and Tasker, G.D.,1974, Progress report on flood magnitude and frequency of Vermont streams: U.S. Geological Survey OpenFile Report 74-130, 37 p.

Lagasse, P.F., Schall, J.D., Johnson, F., Richardson, E.V., Chang, F., 1995, Stream Stability at Highway Structures: Federal Highway Administration Hydraulic Engineering Circular No. 20, Publication FHWA-IP-90-014, 144 p.

Laursen, E.M., 1960, Scour at bridge crossings: Journal of the Hydraulics Division, American Society of Civil Engineers, v. 86, no. HY2, p. 39-53.

Potter, W. D., 1957a, Peak rates of runoff in the Adirondack, White Mountains, and Maine woods area, Bureau of Public Roads

Potter, W. D., 1957b, Peak rates of runoff in the New England Hill and Lowland area, Bureau of Public Roads

Richardson, E.V. and Davis, S.R., 1995, Evaluating scour at bridges: Federal Highway Administration Hydraulic Engineering Circular No. 18, Publication FHWA-IP-90-017, 204 p.

Richardson, E.V., Simons, D.B., and Julien, P.Y., 1990, Highways in the river environment: Federal Highway Administration Publication FHWA-HI-90-016.

Ritter, D.F., 1984, Process Geomorphology: W.C. Brown Co., Debuque, Iowa, 603 p.

Shearman, J.O., 1990, User's manual for WSPRO--a computer model for water surface profile computations: Federal Highway Administration Publication FHWA-IP-89-027, 187 p.

Shearman, J.O., Kirby, W.H., Schneider, V.R., and Flippo, H.N., 1986, Bridge waterways analysis model; research report: Federal Highway Administration Publication FHWA-RD-86-108, 112 p.

Talbot, A.N., 1887, The determination of water-way for bridges and culverts.

U.S. Geological Survey, 1986, Bakersfield, Vermont 7.5 Minute Series quadrangle map: U.S. Geological Survey Topographic Maps, Scale $1: 24,000$. 


\section{APPENDIX A: \\ WSPRO INPUT FILE}




\section{WSPRO INPUT FILE}

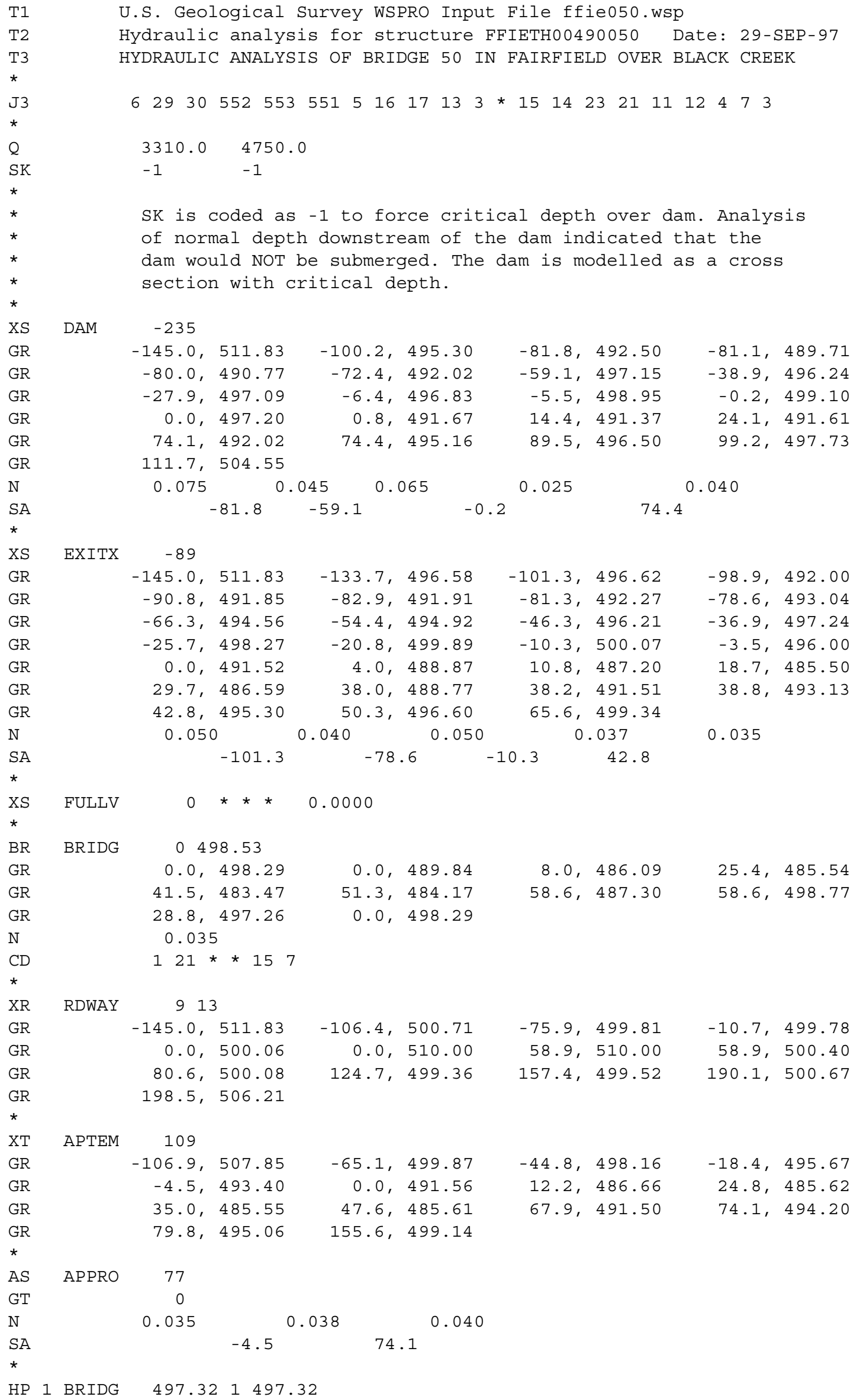




\section{APPENDIX B: \\ WSPRO OUTPUT FILE}




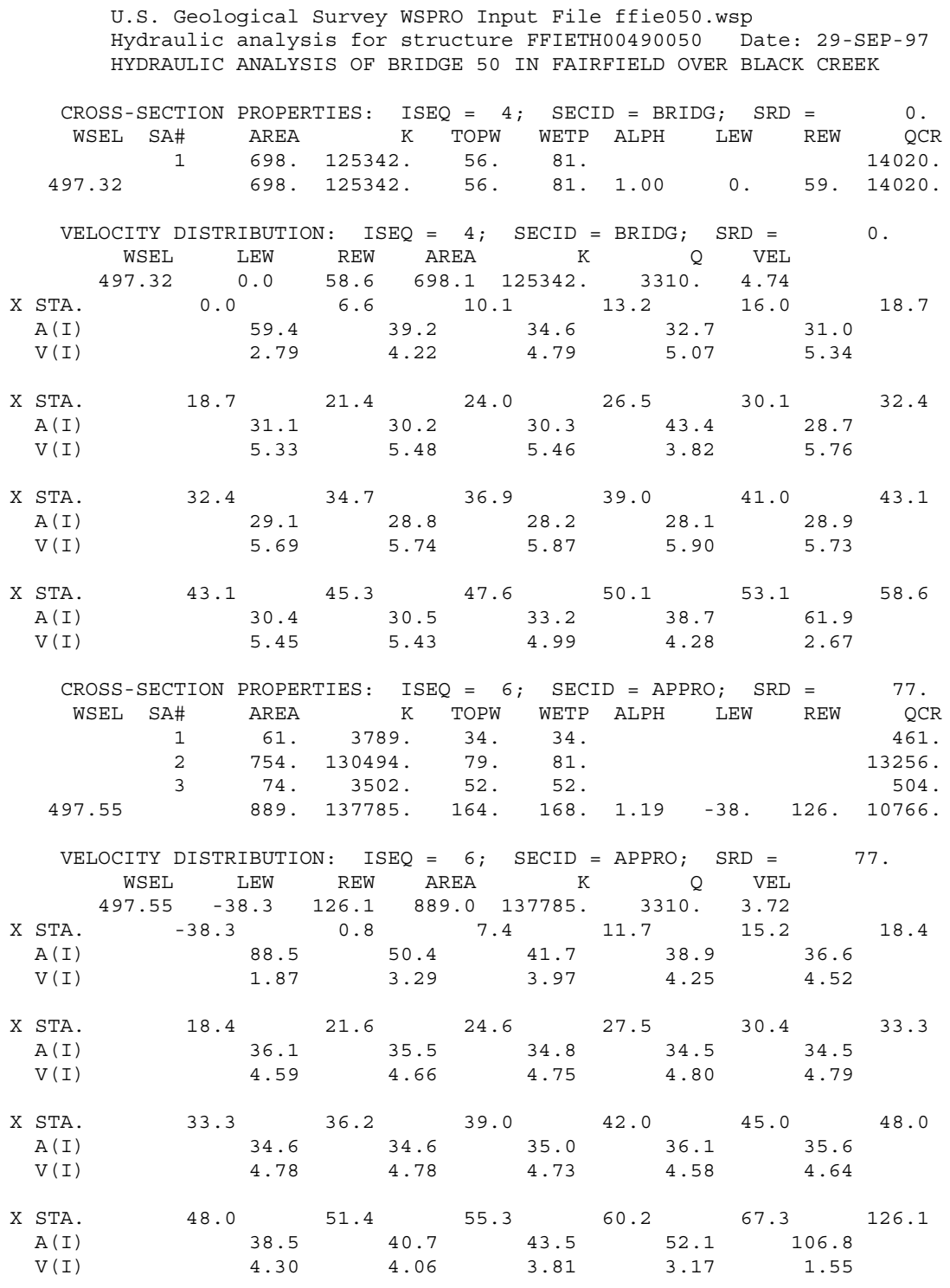


WSPRO OUTPUT FILE (continued)

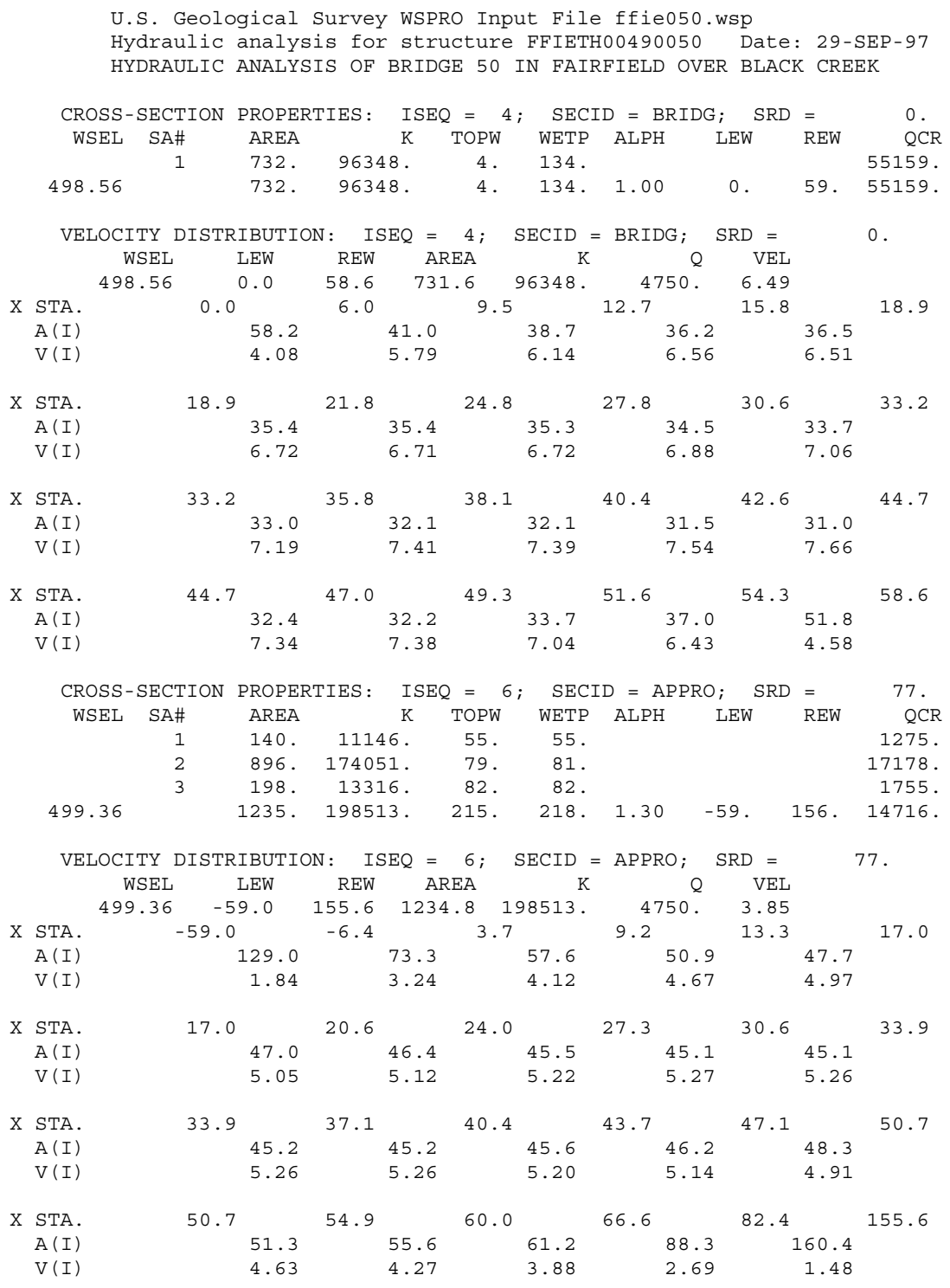


WSPRO OUTPUT FILE (continued)

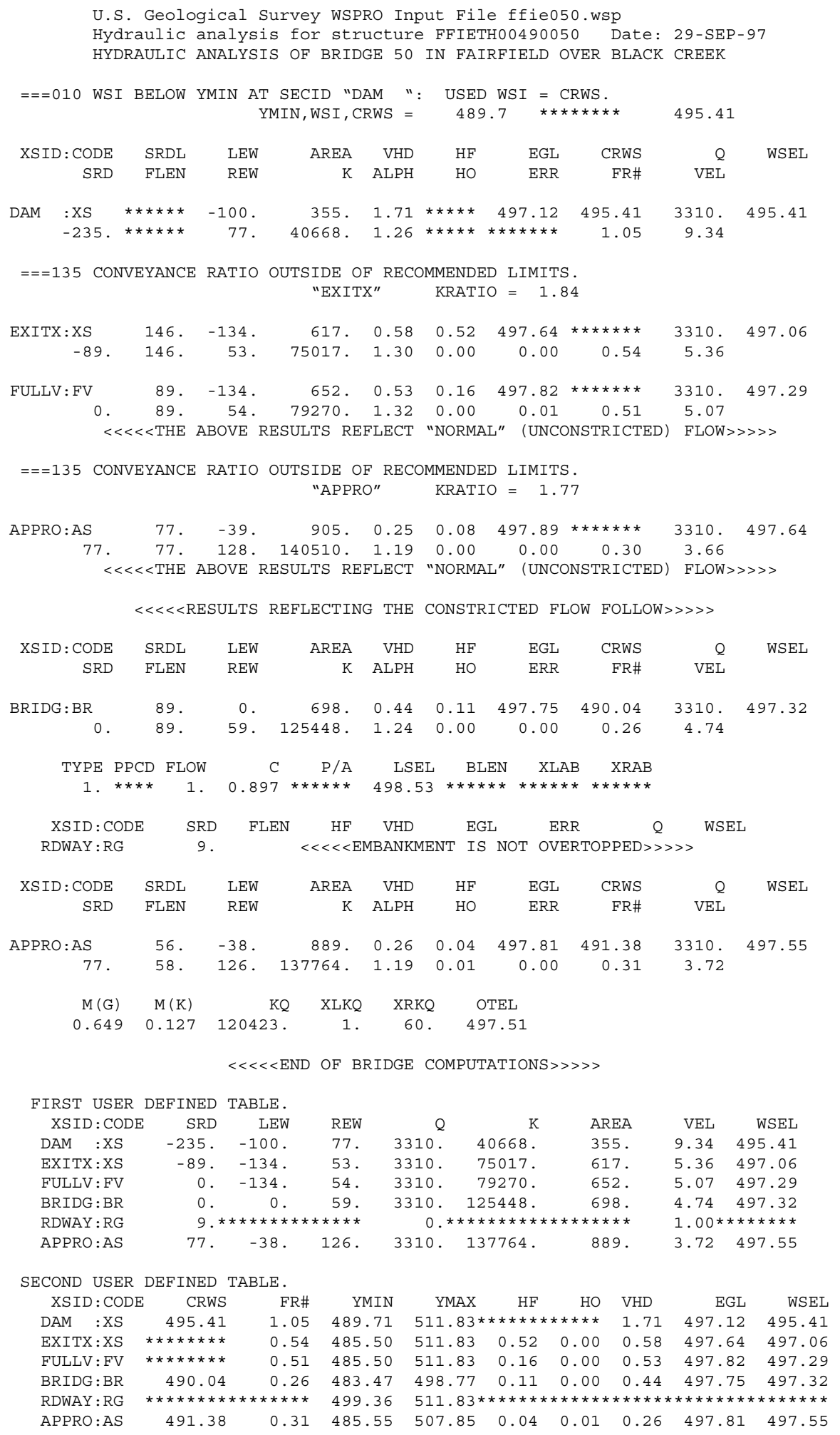


WSPRO OUTPUT FILE (continued)

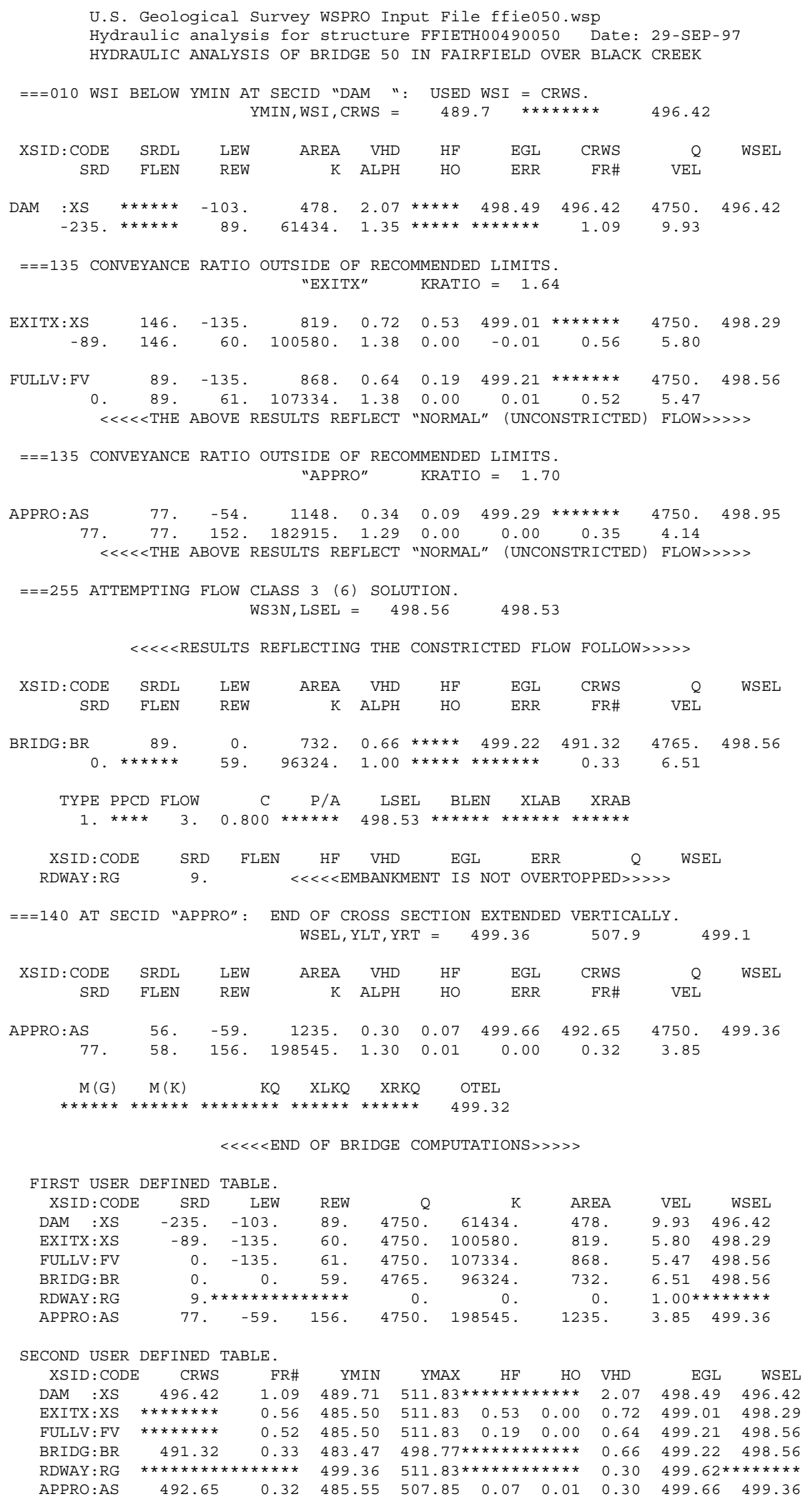




\section{APPENDIX C:}

\section{BED-MATERIAL PARTICLE-SIZE DISTRIBUTION}




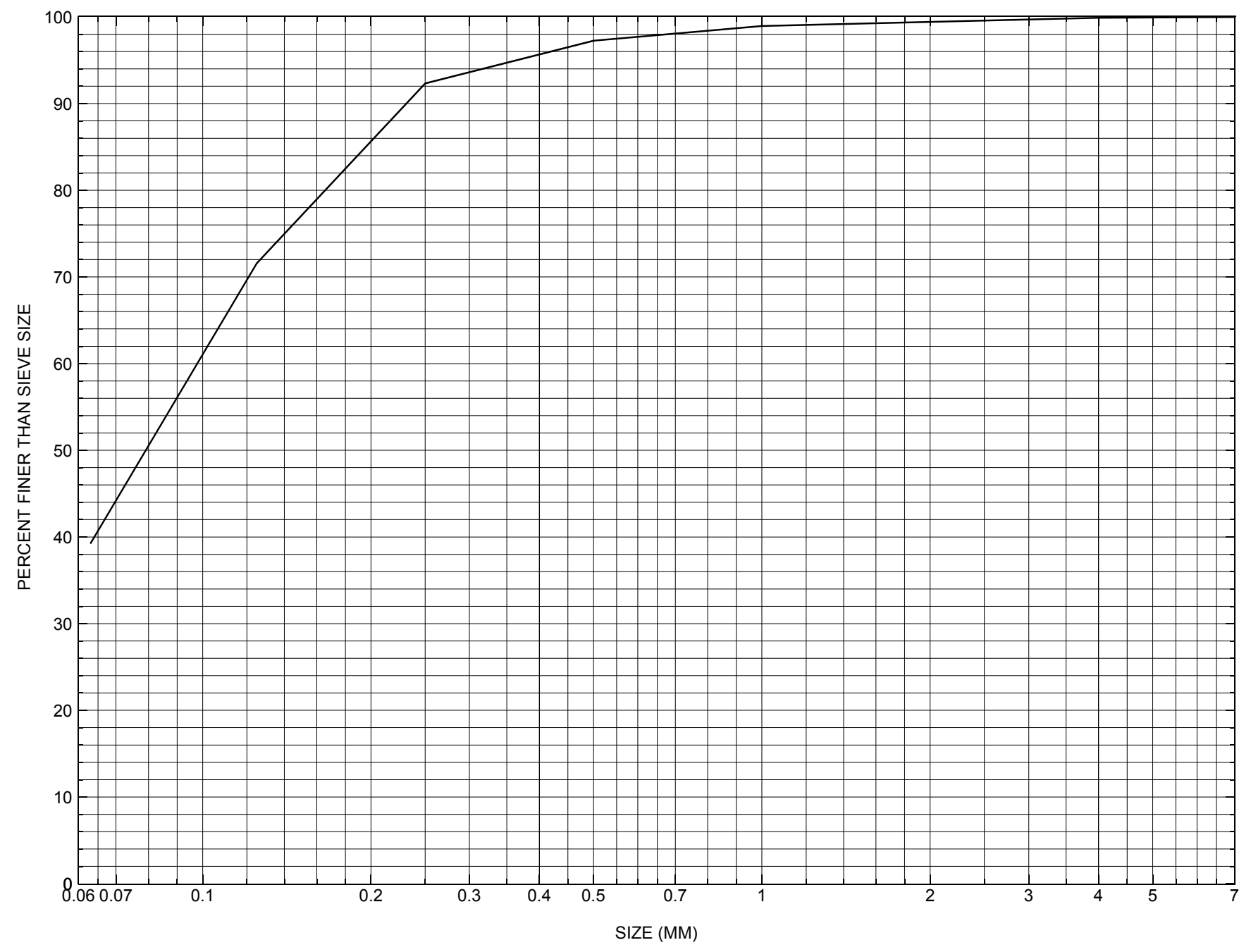

Appendix C. Bed material particle-size distribution for a bed sample taken from the channel approach of structure FFIETH00490050, in Fairfield, Vermont. 


\section{APPENDIX D: \\ HISTORICAL DATA FORM}




\section{Structure Number FFIETH00490050}

\section{General Location Descriptive}

Data collected by (First Initial, Full last name) $\mathbf{E}$. BOEHMLER

Date $(M M / D D / Y Y) \_\mathbf{0 3} / \underline{09} / \underline{95}$

Highway District Number $(I-2 ; n n) \underline{\mathbf{0 8}}$

Town (FIPS place code; I - 4; nnnnn) $\mathbf{2 5 2 2 5}$

Waterway (I - 6) BLACK CREEK

Route Number TH049

Topographic Map Bakersfield

Latitude (I - 16; nnnn.n) $\mathbf{4 4 4 7 2}$
County (FIPS county code; I - 3; nnn)

Mile marker (I - 11; nnn.nnn) $\mathbf{0 0 0 0 0 0}$

Road Name (I - 7): -

Vicinity (I - 9) 0.05 MI TO JCT VT 36

Hydrologic Unit Code: $\mathbf{0 2 0 1 0 0 0 7}$

Longitude (i - 17; nnnnn.n) $\mathbf{7 2 5 1 8}$

\section{Select Federal Inventory Codes}

FHWA Structure Number $(I-8) \quad \mathbf{1 0 0 6 0 5 0 0 5 0 0 6 0 5}$

Maintenance responsibility $(I-21 ; n n) \quad \mathbf{0 3}$

Year built (I - 27; YYYY) 1865

Average daily traffic, ADT (I - 29; nnnnnn) 000000

Year of ADT (I - 30; YY) $\mathbf{9 0}$

Opening skew to Roadway $(I-34 ; n n) \quad \mathbf{0 0}$

Operational status $(I-41 ; X) \mathbf{K}$

Structure type (I- 43; nnn) $\mathbf{7 1 0}$

Approach span structure type (I - 44; nnn) $\mathbf{0 0 0}$

Number of spans (I - 45; nnn) $\mathbf{0 0 1}$

Number of approach spans (I - 46; nnnn) $\mathbf{0 0 0 0}$

Comments:

The structural inspection report of $8 / 29 / 94$ indicates the structure is a wooden, modified, queen post, thrutruss covered bridge. The structure is old and deteriorated and currently closed to vehicular traffic with earth embankment barricades piled at each end. Being closed, a full assessment of the substructure was not performed and evidently has not been performed since at least 1988 . It was recommended to be closed via office memo. of 1/12/1987.
Maximum span length (I - 48; nnnn) 0059

Structure length (I - 49; nnnnnn) $\underline{000070}$

Deck Width (I - 52; nn.n) 131

Channel \& Protection $(I-61 ; n) \quad 5$

Waterway adequacy $(I-71 ; n) \underline{\mathbf{0}}$

Underwater Inspection Frequency $(I-92 B ; X Y Y) \_$N

Year Reconstructed (I - 106) 1967

Clear span (nnn.n ft) _

Vertical clearance from streambed (nnn.n ft) $\underline{\mathbf{5 . 7}}$

Waterway of full opening $\left(n n n . n \mathrm{ft}^{2}\right)$ 


\section{Bridge Hydrologic Data}

Is there hydrologic data available? $\underline{\mathbf{N}}$ if No, type ctrl-n $h \quad$ VTAOT Drainage area $\left(m i^{2}\right)$ : -

Terrain character:

Stream character \& type: -

Streambed material:

Discharge Data (cfs):

$$
\begin{aligned}
& Q_{2.33}- \\
& Q_{50}-
\end{aligned}
$$

Record flood date $(M M / D D / Y Y)$ :

Estimated Discharge (cfs): Ice conditions (Heavy, Moderate, Light) : -

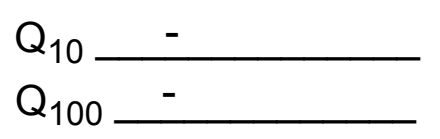

$$
\begin{aligned}
& Q_{25}- \\
& Q_{500}-
\end{aligned}
$$

Water surface elevation $(f t):-$

The stage increases to maximum highwater elevation (Rapidly, Not rapidly):

The stream response is (Flashy, Not flashy):

Describe any significant site conditions upstream or downstream that may influence the stream's stage: -

Watershed storage area (in percent): _ _ \%

The watershed storage area is: - (1-mainly at the headwaters; 2- uniformly distributed; 3-immediatly upstream oi the site)

Water Surface Elevation Estimates for Existing Structure:

\begin{tabular}{|l|l|l|l|l|l|}
\hline Peak discharge frequency & $Q_{2.33}$ & $Q_{10}$ & $Q_{25}$ & $Q_{50}$ & $Q_{100}$ \\
Water surface elevation (ft)) & - & - & - & - & - \\
Velocity (ft/sec) & - & - & - & - & - \\
\hline
\end{tabular}

Long term stream bed changes: -

Is the roadway overtopped below the $\mathrm{Q}_{100}$ ? (Yes, No, Unknown): $\mathbf{U}$ Frequency: Relief Elevation (ft): Discharge over roadway at $Q_{100}\left(f^{3} / \mathrm{sec}\right)$ :

Are there other structures nearby? (Yes, No, Unknown): $\underline{\mathbf{U}}$ Upstream distance (miles): Town: If No or Unknown, type ctrl-n os Highway No. : Structure No. : Year Built:

Clear span (ft): Clear Height $(f t)$ : Full Waterway $\left(f^{2}\right)$ : 
Downstream distance (miles): Town: Year Built:

Highway No. : Structure No. : Structure Type:

Clear span (ft): Clear Height $(f t)$ : Full Waterway $\left(f^{2}\right)$ : -

Comments:

\section{USGS Watershed Data}

Watershed Hydrographic Data

Drainage area $(D A) \stackrel{35.15}{3 \mathrm{mi}^{2}}$

Watershed storage (ST)

Bridge site elevation 374 0.5 Main channel length 15.3 $\%$ $10 \%$ channel length elevation $\mathbf{3 9 4}$ $\mathrm{ft} \quad 85 \%$ channel length elevation 720 $\mathrm{ft}$

Main channel slope $(S)$

(S) 28.4 $\mathrm{ft} / \mathrm{mi}$

Watershed Precipitation Data

Average site precipitation in Average headwater precipitation in

Maximum 2yr-24hr precipitation event $(124,2)$ in

Average seasonal snowfall $(S n)$ $\mathrm{ft}$ 


\section{Bridge Plan Data}

Are plans available? If no, type ctrl-n pl

Project Number --

Minimum channel bed elevation: --

Datum (NAD27, NAD83, Other): --

Low superstructure elevation: USLAB -DSLAB --

Benchmark location description:

NO BENCHMARK INFORMATION

Reference Point (MSL, Arbitrary, Other): --

Foundation Type: 4

If 1: Footing Thickness _-

If 2: Pile Type:

If 3 : Footing bottom elevation:

Is boring information available? $\mathrm{N}$

(1-Spreadfooting; 2-Pile; 3- Gravity; 4-Unknown) USRAB -Footing bottom elevation: --

Foundation Material Type: $\mathbf{3}$

Briefly describe material at foundation bottom elevation or around piles:

NO FOUNDATION MATERIAL INFORMATION

Comments:

NO PLANS. 


\section{Cross-sectional Data}

Is cross-sectional data available? $\mathbf{N}$ If no, type ctrl-n xs

Source (FEMA, VTAOT, Other)? -

Comments: NO CROSS SECTION INFORMATION

\begin{tabular}{|l|l|l|l|l|l|l|l|l|l|l|l|}
\hline Station & - & - & - & - & - & - & - & - & - & - & - \\
\hline Feature & - & - & - & - & - & - & - & - & - & - & - \\
\hline $\begin{array}{l}\text { Low chord } \\
\text { elevation }\end{array}$ & - & - & - & - & - & - & - & - & - & - & - \\
\hline $\begin{array}{l}\text { Bed } \\
\text { elevation }\end{array}$ & - & - & - & - & - & - & - & - & - & - & - \\
\hline $\begin{array}{l}\text { Low chord } \\
\text { to bed }\end{array}$ & - & - & - & - & - & - & - & - & - & - & - \\
\hline Station & - & - & - & - & - & - & - & - & - & - & - \\
\hline Feature & - & - & - & - & - & - & - & - & - & - & - \\
\hline $\begin{array}{l}\text { Low chord } \\
\text { elevation }\end{array}$ & - & - & - & - & - & - & - & - & - & - & - \\
\hline $\begin{array}{l}\text { Bed } \\
\text { elevation }\end{array}$ & - & - & - & - & - & - & - & - & - & - & - \\
\hline $\begin{array}{l}\text { Low chord } \\
\text { to bed }\end{array}$ & - & - & - & - & - & - & - & - & - & - & - \\
\hline
\end{tabular}

Source (FEMA, VTAOT, Other)?

Comments: NO CROSS SECTION INFORMATION

\begin{tabular}{|l|l|l|l|l|l|l|l|l|l|l|l|}
\hline Station & - & - & - & - & - & - & - & - & - & - & - \\
\hline Feature & - & - & - & - & - & - & - & - & - & - & - \\
\hline $\begin{array}{l}\text { Low chord } \\
\text { elevation }\end{array}$ & - & - & - & - & - & - & - & - & - & - & - \\
\hline $\begin{array}{l}\text { Bed } \\
\text { elevation }\end{array}$ & - & - & - & - & - & - & - & - & - & - & - \\
\hline $\begin{array}{l}\text { Low chord } \\
\text { to bed }\end{array}$ & - & - & - & - & - & - & - & - & - & - & - \\
\hline Station & - & - & - & - & - & - & - & - & - & - & - \\
\hline Feature & - & - & - & - & - & - & - & - & - & - & - \\
\hline $\begin{array}{l}\text { Low chord } \\
\text { elevation }\end{array}$ & - & - & - & - & - & - & - & - & - & - & - \\
\hline $\begin{array}{l}\text { Bed } \\
\text { levation }\end{array}$ & - & - & - & - & - & - & - & - & - & - & - \\
\hline $\begin{array}{l}\text { Low chord } \\
\text { to bed }\end{array}$ & - & - & - & - & - & - & - & - & - & - & - \\
\hline
\end{tabular}




\section{APPENDIX E: \\ LEVEL I DATA FORM}


U. S. Geological Survey

Bridge Field Data Collection and Processing Form

Qa/Qc Check by: RB Date: $3 / 7 / 96$

\section{Structure Number FFIETH00490050}

Computerized by: $\underline{\mathbf{R B}}$ Date: $3 / 7 / 96$

Reviewd by: SAO Date: $\underline{6}$ /1/98

\section{A. General Location Descriptive}

1. Data collected by (First Initial, Full last name) L. MEDALIE

Date $(M M / D D / Y Y)$

2. Highway District Number $\mathbf{0 8}$

Mile marker 000

County FRANKLIN (011)

Town FAIRFIELD (25225)

Waterway (I - 6) BLACK CREEK

Route Number TH049

Road Name -

3. Descriptive comments:

Hydrologic Unit Code: 02010007

Located 0.05 miles south along Town Highway 49 from its junction with Vermont State Highway 36.

\section{B. Bridge Deck Observations}
4. Surface cover... LBUS 4
RBUS 4
LBDS 5
RBDS 4
Overall 4

(2b us, ds,lb,rb: 1- Urban; 2- Suburban; 3- Row crops; 4- Pasture; 5- Shrub- and brushland; 6- Forest; 7- Wetland)
5. Ambient water surface... US 1
UB 1
DS 1
(1- pool; 2- riffle)

6. Bridge structure type 1 (1- single span; 2- multiple span; 3- single arch; 4- multiple arch; 5-cylindrical culvert; 6- box culvert; or 7- other)
7. Bridge length $\mathbf{7 0}$
(feet)
Span length $\underline{\mathbf{5 9}}$
(feet)
Bridge width 13.1 (feet)

\section{Road approach to bridge:}
8. LB 2 RB 1
( 0 even, 1- lower, 2- higher)
9. LB 1
RB 1
(1-Paved, 2- Not paved)

10. Embankment slope (run / rise in feet / foot)

$$
\text { US left }
$$

0.0:1

US right

0.0:1

\begin{tabular}{|c|c|c|c|c|}
\hline & \multicolumn{2}{|c|}{ Protection } & \multirow{2}{*}{ 13.Erosion } & \multirow{2}{*}{ 14.Severity } \\
\hline & 11.Type & 12.Cond. & & \\
\hline LBUS & $\mathbf{0}$ & - & $\mathbf{0}$ & - \\
\hline RBUS & 2 & 1 & $\mathbf{0}$ & - \\
\hline RBDS & $\mathbf{0}$ & - & $\mathbf{0}$ & - \\
\hline LBDS & 0 & - & 0 & - \\
\hline
\end{tabular}

Bank protection types: 0- none; 1- < 12 inches;

2- < 36 inches; 3- < 48 inches;

4- $<60$ inches; 5- wall / artificial levee

Bank protection conditions: 1- good; 2- slumped;

3- eroded; 4- failed

Erosion: 0 - none; 1- channel erosion; 2-

road wash; 3- both; 4- other

Erosion Severity: 0 - none; 1- slight; 2- moderate; 3- severe

\section{Channel approach to bridge (BF):}

15. Angle of approach: 15

16. Bridge skew: 10

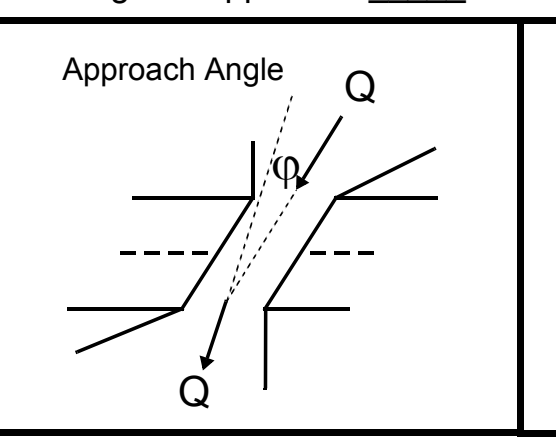

17. Channel impact zone 1 :

Where? LB (LB, RB)

Exist? $\mathbf{Y}(Y$ or $N)$ Bridge Skew Angle

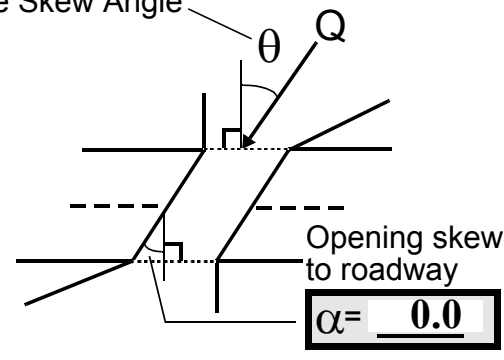

Range? 40 feet DS

Severity 2

Channel impact zone 2:

Where? $(L B, R B)$

(US, UB, DS)

$D S)$ 140

Exist? $\underline{\mathbf{N}}(\mathrm{Y}$ or $N)$

Severity -

Range? - feet (US, UB, DS) to feet -

Impact Severity: 0- none to very slight; 1- Slight; 2- Moderate; 3- Severe 
18. Bridge Type: 1a

1a- Vertical abutments with wingwalls

$1 \mathrm{~b}$ - Vertical abutments without wingwalls

2- Vertical abutments and wingwalls, sloping embankment Wingwalls parallel to abut. face

3- Spill through abutments

4- Sloping embankment, vertical wingwalls and abutments

Wingwall angle less than $90^{\circ}$.

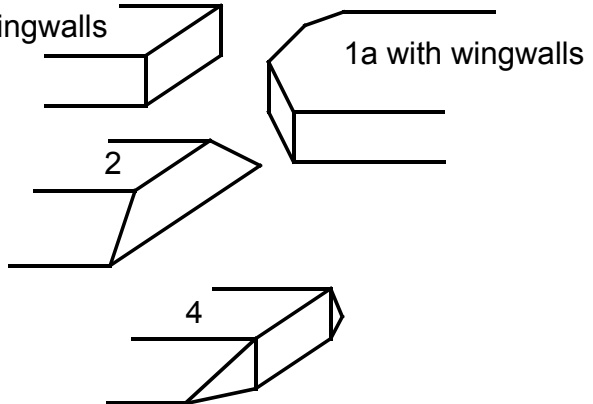

19. Bridge Deck Comments (surface cover variations, measured bridge and span lengths, bridge type variations, approach overflow width, etc.)

4. Some trees on the downstream left overbank. There are row crops 200 feet downstream on the left overbank. On the left bank upstream, there is a 20 foot strip of brush adjacent to the channel. The upstream right bank is lawn with a house within 1 bridge length then brush and trees.

7. Values are from the VAOT files. Measured span length is 63 feet, bridge length is 72 feet, and the bridge width is 16 feet.

8. The left bank road approach is level with the bridge for $25 \mathrm{ft}$ then increases in elevation.

11. The upstream right road approach protection consists of a $25 \mathrm{ft}$ long stone wall. The downstream right road approach is protected by the wingwall.

18. This is a type 1 a bridge except on the upstream right which is type $1 \mathrm{~b}$.

\section{Upstream Channel Assessment}

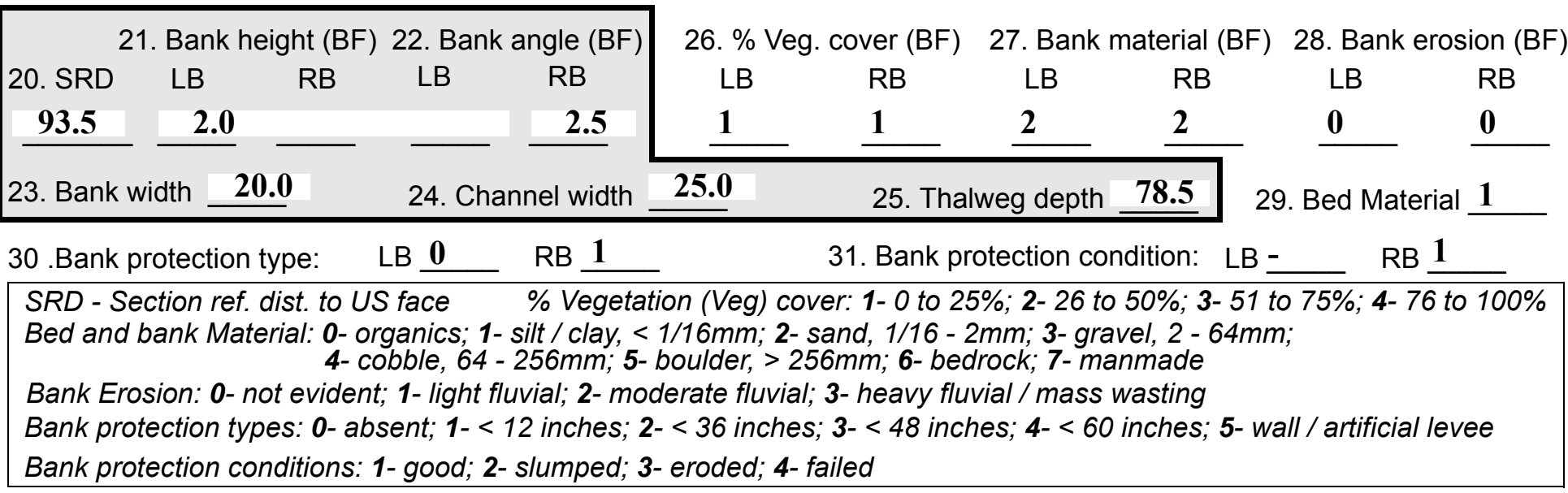

32. Comments (bank material variation, minor inflows, protection extent, etc.):

30. The right bank has some type 2 protection, but is mostly type 1 .

$500 \mathrm{ft}$ US is a large bedrock control and waterfall into calm water.

$250 \mathrm{ft}$ US is a bedrock outcrop on the right bank behind which is a cutbank due to an eddy vortex. 
33.Point/Side bar present? $\mathbf{N}(Y$ or $N$. if $N$ type ctrl-n pb)34. Mid-bar distance: -

35. Mid-bar width:

36. Point bar extent: feet (US, UB) to feet (US, UB, DS) positioned $\%$ LB to $\% \mathrm{RB}$

37. Material:

38. Point or side bar comments (Circle Point or Side; Note additional bars, material variation, status, etc.):

NO POINT BARS

39. Is a cut-bank present? $\underline{\mathbf{N}}$ (Y or if $\mathrm{N}$ type ctrl-n cb)

40. Where? (LB or $R B)$

41. Mid-bank distance: -

42. Cut bank extent: feet (US, UB) to feet (US, UB, DS)

43. Bank damage: (1- eroded and/or creep; 2- slip failure; 3- block failure)

44. Cut bank comments (eg. additional cut banks, protection condition, etc.):

NO CUT BANKS

45. Is channel scour present? $\mathbf{N}$ ( $Y$ or if $N$ type ctrl-n cs)

47. Scour dimensions: Length Width Depth : 46. Mid-scour distance: -

48. Scour comments (eg. additional scour areas, local scouring process, etc.):

NO CHANNEL SCOUR

49. Are there major confluences? $\mathbf{N}$

51. Confluence 1: Distance Confluence 2: Distance 52. Enters on Enters on 54. Confluence comments (eg. confluence name):

\section{NO MAJOR CONFLUENCES}

50. How many? -

53. Type(1-perennial; 2- ephemeral)

Type (1-perennial; 2-ephemeral) ( $L B$ or $R B)$

\section{Under Bridge Channel Assessment}

55. Channel restraint (BF)? LB 2

\begin{tabular}{|c|c|c|c|}
\hline \multicolumn{2}{|c|}{ 56. Height (BF) } & \multicolumn{2}{|c|}{57 Angle (BF) } \\
\hline LB & RB & LB & RB \\
\hline 68 & & \multicolumn{2}{|c|}{60} \\
\hline
\end{tabular}

58. Bank width (BF) (1- natural bank; 2- abutment; 3- artificial levee)

Bed and bank Material: 0- organics; 1- silt / clay, < 1/16mm; 2- sand, 1/16 - 2mm; 3- gravel, 2 - 64mm; 4- cobble, 64 - 256mm; 5- boulder, > 256mm; 6- bedrock; 7- manmade

\begin{tabular}{lclc} 
61. Material (BF) & \multicolumn{3}{l}{ 62. Erosion (BF) } \\
LB & RB & LB & RB \\
$\mathbf{2}$ & $\mathbf{7}$ & $\mathbf{7}$ & - \\
\hline
\end{tabular}

60. Thalweg depth $\lcm{90.0}$

63. Bed Material -

Bank Erosion: 0- not evident; 1- light fluvial; 2- moderate fluvial; 3- heavy fluvial / mass wasting

64. Comments (bank material variation, minor inflows, protection extent, etc.):

1

63. Some stones are in the channel. 
65. Debris and Ice Is there debris accumulation?

67. Debris Potential ( 1- Low; 2- Moderate; 3- High)

69. Is there evidence of ice build-up? 1 (Y or $N)$

70. Debris and Ice Comments:

1
$(Y$ or $N)$ 66. Where? $\mathbf{N}$

68. Capture Efficiency 1

(1- Upstream; 2- At bridge; 3-Both)

Ice Blockage Potential $\mathbf{N}$
(1- Low; 2- Moderate; 3- High)

(1-Low; 2- Moderate; 3- High)

\begin{tabular}{|l|c|c|c|c|c|c|c|c|}
\hline Abutments & $\begin{array}{c}\text { 71. Attack } \\
\angle \text { (BF) }\end{array}$ & $\begin{array}{c}\text { 72. Slope } \angle \\
\text { (Qmax) }\end{array}$ & $\begin{array}{c}\text { 73. Toe } \\
\text { loc. (BF) }\end{array}$ & $\begin{array}{c}\text { 74. Scour } \\
\text { Condition }\end{array}$ & $\begin{array}{c}75 . \text { Scour } \\
\text { depth }\end{array}$ & $\begin{array}{c}\text { 76. Exposure } \\
\text { depth }\end{array}$ & 77. Material & 78. Length \\
\hline LABUT & & $\mathbf{1 5}$ & $\mathbf{9 0}$ & $\mathbf{2}$ & $\mathbf{2}$ & $\mathbf{0}$ & $\mathbf{0 . 2 5}$ & $\mathbf{9 0 . 0}$ \\
\hline RABUT & $\mathbf{2}$ & - & $\mathbf{9 0}$ & & & $\mathbf{2}$ & $\mathbf{3}$ & $\mathbf{5 8 . 5}$ \\
\hline
\end{tabular}

Pushed: $L B$ or RB

Toe Location (Loc.): 0- even, 1- set back, 2- protrudes

Scour cond.: 0- not evident; 1- evident (comment); 2- footing exposed; 3-undermined footing; 4- piling exposed; 5- settled; 6- failed

Materials: 1- Concrete; 2- Stone masonry or drywall; 3- steel or metal; 4- wood

79. Abutment comments (eg. undermined penetration, unusual scour processes, debris, etc.):

1

1

1,2

74. The upstream end of the right abutment is undermined $1 \mathrm{ft}$.

77. The upstream end of the right abutment is stone faced with concrete. The downstream end of the right abutment is composed of piled stones. The gaps between stones are as much as 2 feet deep.

76. A footing (or more stone) on the left abutment was detected when poking with the range pole, but the footing is not exposed along the length of the abutment.

80. Wingwalls:

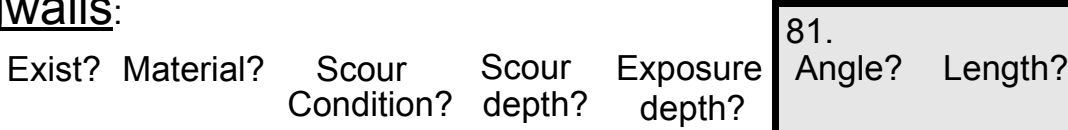

USLWW:

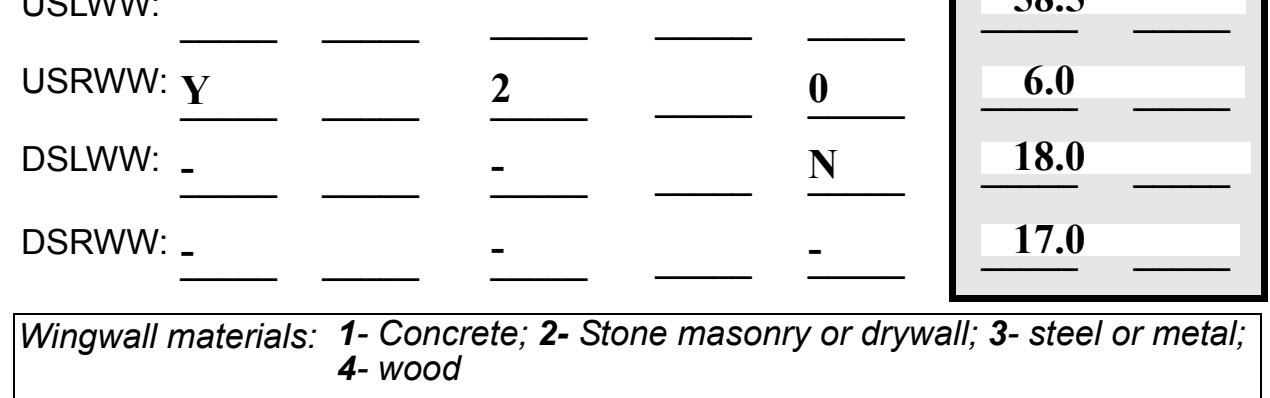

58.5

4- wood

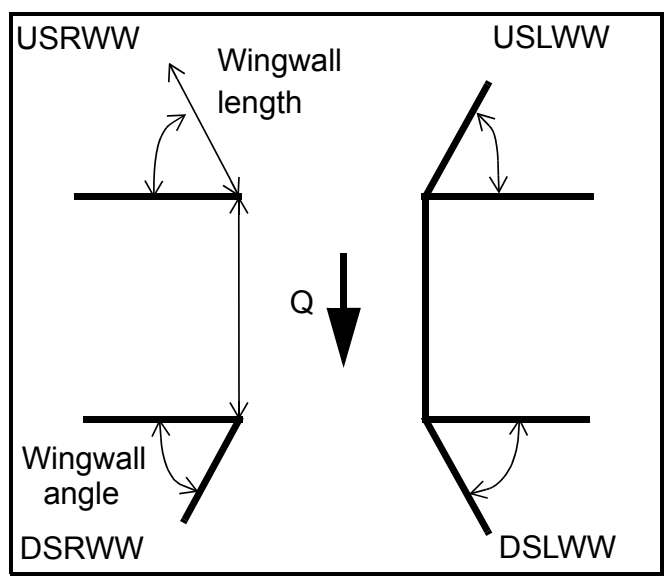

82. Bank / Bridge Protection:

\begin{tabular}{|l|l|l|l|l|l|l|l|l|}
\hline Location & USLWW & USRWW & LABUT & RABUT & LB & RB & DSLWW & DSRWW \\
\hline Type & - & $\mathbf{2}$ & $\mathbf{Y}$ & $\mathbf{1}$ & $\mathbf{1}$ & - & - & $\mathbf{1}$ \\
\hline Condition & $\mathbf{Y}$ & - & $\mathbf{1}$ & - & $\mathbf{2}$ & - & - & $\mathbf{4}$ \\
\hline Extent & $\mathbf{1}$ & $\mathbf{0 . 5}$ & $\mathbf{1}$ & $\mathbf{2}$ & - & $\mathbf{0}$ & $\mathbf{2}$ & - \\
\hline
\end{tabular}

Bank / Bridge protection types: 0- absent; 1- < 12 inches; 2- < 36 inches; 3- < 48 inches; 4- < 60 inches; 
83. Wingwall and protection comments (eg. undermined penetration, unusual scour processes, etc.):

-
-
-
-
-
1
1
4
0
-
-

\section{Piers:}

84. Are there piers? 80. (Y or if $N$ type ctrl-n pr)

\begin{tabular}{|l|l|l|l|l|l|l|l|}
\hline \multirow{2}{*}{$\begin{array}{l}85 . \\
\text { Pier no. }\end{array}$} & \multicolumn{3}{|c|}{ width (w) feet } & \multicolumn{3}{c|}{ elevation (e) feet } \\
\cline { 2 - 9 } & w1 & w2 & w3 & e@w1 & e@w2 & e@w3 \\
\hline Pier 1 & & & - & $\mathbf{3 0 . 0}$ & $\mathbf{1 5 . 5}$ & - \\
\hline Pier 2 & & & & $\mathbf{9 0 . 0}$ & $\mathbf{3 7 . 5}$ & $\mathbf{3 0 . 0}$ \\
\hline Pier 3 & & - & - & $\mathbf{2 7 . 5}$ & - & - \\
\hline Pier 4 & - & - & - & - & - & - \\
\hline
\end{tabular}

\begin{tabular}{|l|l|l|l|l|}
\hline Level 1 Pier Descr. & \multicolumn{1}{|c|}{1} & \multicolumn{1}{|c|}{2} & \multicolumn{1}{|c|}{3} & \multicolumn{1}{|c|}{ 86. Location (BF) } \\
\hline 87. Type & The & on a & is & There \\
\hline 88. Material & dow & bed- & erod & are \\
\hline 89. Shape & nstre & rock & ed/ & crac \\
\hline 90. Inclined? & am & expo & spall & ks in \\
\hline 91. Attack $\angle$ (BF) & wight & sure. & ed & the \\
\hline 92. Pushed & wall & bot- & 1 & crete \\
\hline 93. Length (feet) & - & - & - & - \\
\hline 94. \# of piles & is & tom & foot & up to \\
\hline 95. Cross-members & con- & of & abov & 6 in \\
\hline 96. Scour Condition & crete & the & e the & wide. \\
\hline 97. Scour depth & and & con- & bed- & On \\
\hline 98. Exposure depth & sits & crete & rock. & the \\
\hline
\end{tabular}

LFP, LTB, LB, MCL, MCM, MCR, RB, RTB, RFP

1- Solid pier, 2- column, 3- bent

1-Wood; 2- concrete; 3- metal; 4- stone

1- Round; 2- Square; 3- Pointed

Y-yes; N- no

$L B$ or $R B$

0- none; 1- laterals; 2- diagonals; 3- both

0- not evident; 1- evident (comment);

2- footing exposed; 3- piling exposed;

4- undermined footing; 5 - settled; 6 - failed 
99. Pier comments (eg. undermined penetration, protection and protection extent, unusual scour processes, etc.):

downstream left wingwall, there are also some cracks and the top of the footing is exposed. There are $1 \mathrm{ft}$ lateral gaps between stones of the wingwall.

82. The protection for the downstream left wingwall and the right abutment is a few sporadic stones that cover the footing of the wingwall and extend the entire length of the abutment.

$\mathbf{N}$

100.

\section{E. Downstream Channel Assessment}

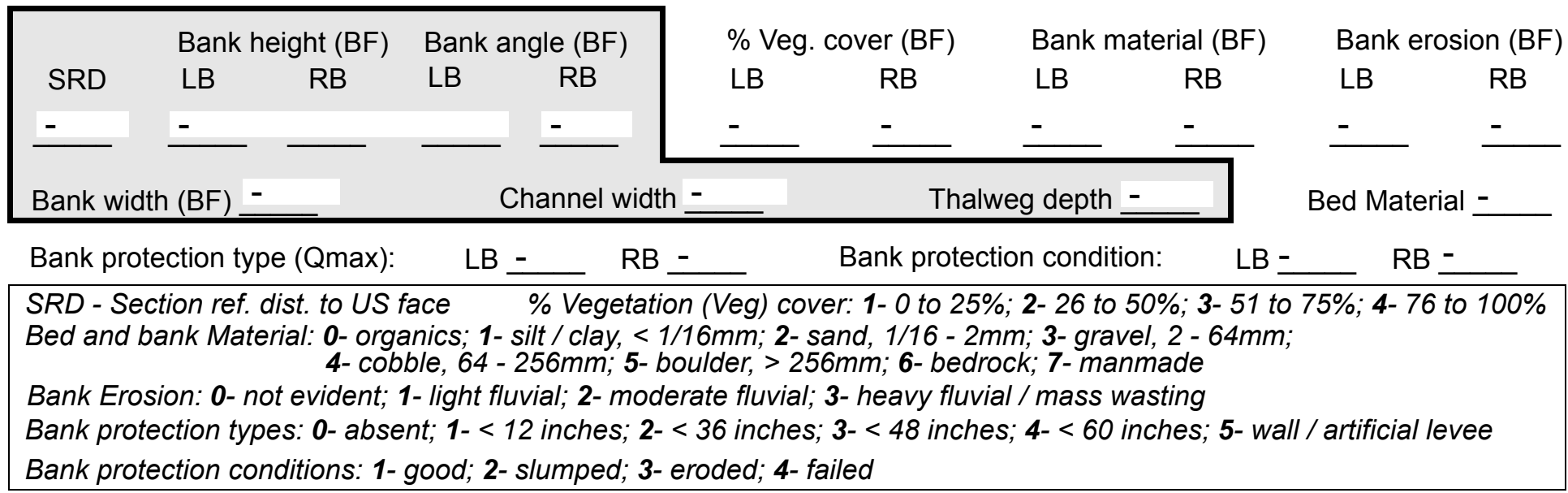

Comments (eg. bank material variation, minor inflows, protection extent, etc.):

$-$

$-$

$-$

$-$

$-$

$-$

$-$

$-$

$-$

$-$

$-$

$-$

101. Is a drop structure present? _ ( $Y$ or $N$, if $N$ type ctrl-n ds) 102. Distance: ___ feet
103. Drop: - feet
104. Structure material: -
(1- steel sheet pile; 2- wood pile; 3- concrete; 4- other)

105. Drop structure comments (eg. downstream scour depth): 
106. Point/Side bar present? (Y or $N$. if $N$ type ctrl-n pb)Mid-bar distance:

Mid-bar width: -

Point bar extent: feet -

(US, UB, DS) to feet (US, UB, DS) positioned $\%$ LB to $\% \mathrm{RB}$ Material:

Point or side bar comments (Circle Point or Side; note additional bars, material variation, status, etc.):

$\underline{\text { Is a cut-bank present? }} \mathbf{N}$ (Y or if $N$ type ctrl- $n$ cb) Where? $\underline{\mathbf{O}}$ (LB or RB) Mid-bank distance: $\underline{\text { PIE }}$ Cut bank extent: $\underline{\mathbf{R S}}$ feet __ (US, UB, DS) to feet (US, UB, DS)

Bank damage: (1- eroded and/or creep; 2- slip failure; 3- block failure)

Cut bank comments (eg. additional cut banks, protection condition, etc.):

Is channel scour present? ( $Y$ or if $N$ type ctrl-n cs) Width 542 Depth: 6

Mid-scour distance: 2

Scour dimensions: Length 1

Scour comments (eg. additional scour areas, local scouring process, etc.):

541

1

5

1

Are there major confluences? 2 2 ( $Y$ or if $N$ type ctrl-n $m c$ )

Confluence 1: Distance left Enters on ban ( $L B$ or RB)

Enters on pose ( $L B$ or $R B)$

Confluence 2: Distance com-

Confluence comments (eg. confluence name):

a wingwall for $40 \mathrm{ft}$, then a spillway opening for $20 \mathrm{ft}$, and then protection for $100 \mathrm{ft}$. The right bank is composed of a wingwall for $30 \mathrm{ft}$, then bedrock for $50 \mathrm{ft}$, followed by a wooden

\section{F. Geomorphic Channel Assessment}

107. Stage of reach evolution
1- Constructed

2- Stable

3- Aggraded

4- Degraded

5- Laterally unstable

6- Vertically and laterally unstable 
108. Evolution comments (Channel evolution not considering bridge effects; See HEC-20, Figure 1 for geomorphic descriptors):

aining wall for $50 \mathrm{ft}$. 


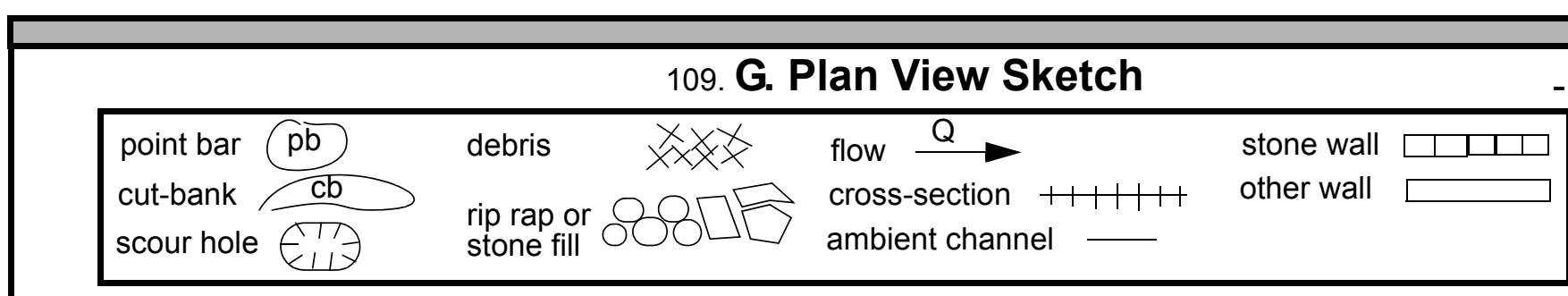


APPENDIX F:

SCOUR COMPUTATIONS 
SCOUR COMPUTATIONS

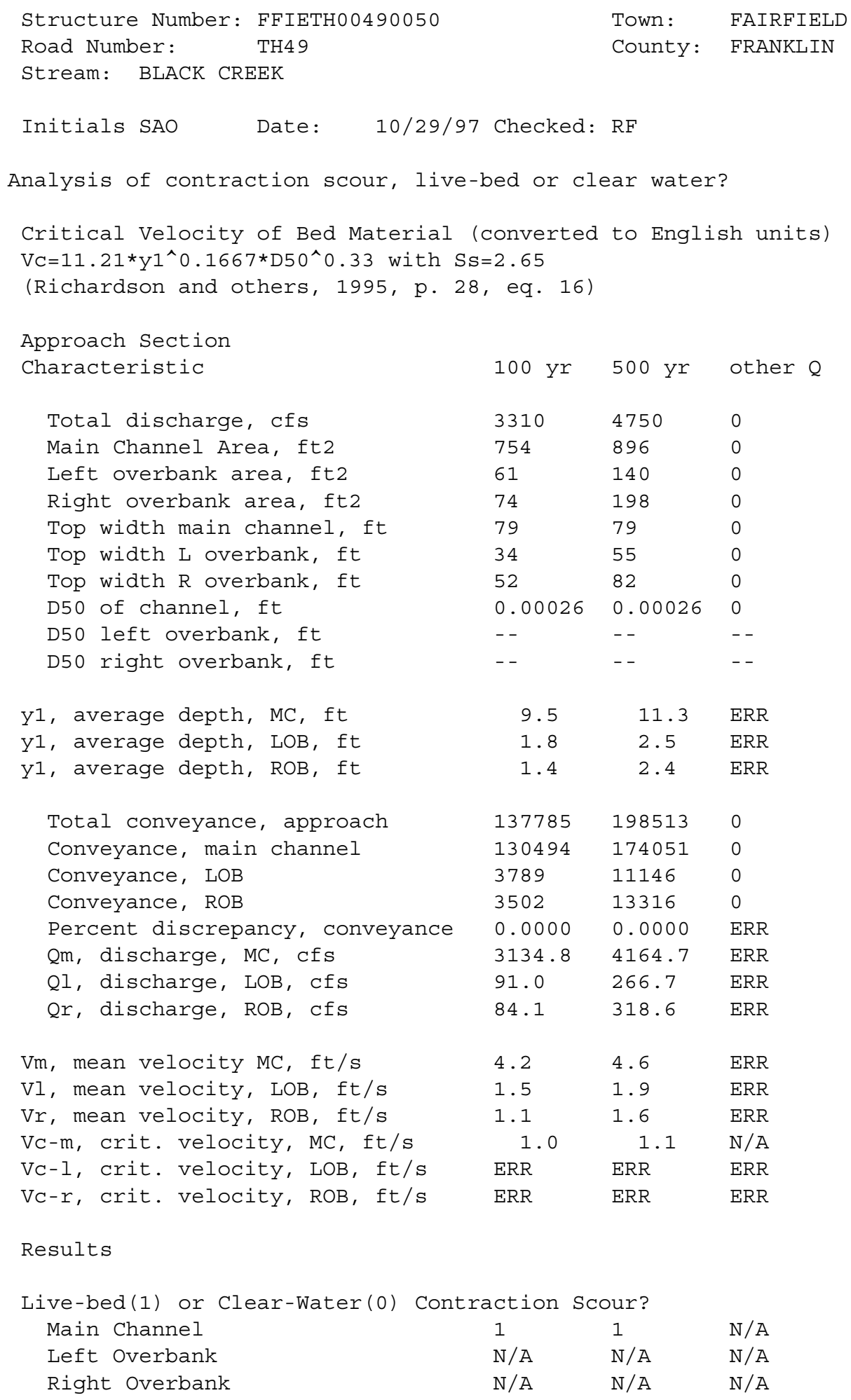




\begin{tabular}{|c|c|c|c|c|c|c|}
\hline \multicolumn{7}{|c|}{$\begin{array}{l}\text { Hive-Bed Contraction Scour } \\
\text { Laursen's Live Bed Contraction Scour } \\
\mathrm{y} 2 / \mathrm{y} 1=(\mathrm{Q} 2 / \mathrm{Q} 1)^{\wedge}(6 / 7) *(\mathrm{~W} 1 / \mathrm{W} 2)^{\wedge}(\mathrm{k} 1) \\
\mathrm{ys}=\mathrm{y} 2-\mathrm{y} \text { bridge } \\
\text { (Richardson and others, 1995, p. 30, eq. } 17 \text { and 18) } \\
\text { Approach }\end{array}$} \\
\hline Characteristic & $100 \mathrm{yr}$ & 500 yr & Other Q & $100 \mathrm{yr}$ & $500 \mathrm{yr}$ & Other Q \\
\hline Q1, discharge, cfs & 3310 & 4750 & 0 & 3310 & 4750 & 0 \\
\hline Total conveyance & 137785 & 198513 & 0 & 125342 & 96348 & 0 \\
\hline Main channel conveyance & 130494 & 174051 & 0 & 125342 & 96348 & 0 \\
\hline Main channel discharge & 3135 & 4165 & ERR & 3310 & 4750 & ERR \\
\hline Area - main channel, ft2 & 754 & 896 & 0 & 698 & 732 & 0 \\
\hline (W1) channel width, ft & 79 & 79 & 0 & 58.6 & 58.6 & 0 \\
\hline (Wp) cumulative pier width, ft & 0 & 0 & 0 & 0 & 0 & 0 \\
\hline w1, adjusted bottom width(ft) & 79 & 79 & 0 & 58.6 & 58.6 & 0 \\
\hline D50, ft & 0.00026 & 0.00026 & 0.00026 & & & \\
\hline w, fall velocity, ft/s (p. 32) & 0.015 & 0.015 & 0 & & & \\
\hline y, ave. depth flow, ft & 9.54 & 11.34 & $\mathrm{~N} / \mathrm{A}$ & 11.91 & 12.49 & ERR \\
\hline S1, slope EGL & 0.00091 & 0.001 & 0 & & & \\
\hline $\mathrm{P}$, wetted perimeter, $\mathrm{MC}$, ft & 81 & 81 & 0 & & & \\
\hline R, hydraulic Radius, ft & 9.309 & 11.062 & ERR & & & \\
\hline $\mathrm{V}^{*}$, shear velocity, ft/s & 0.522 & 0.597 & $\mathrm{~N} / \mathrm{A}$ & & & \\
\hline $\mathrm{V} * / \mathrm{w}$ & 34.818 & 39.788 & ERR & & & \\
\hline $\begin{array}{l}\text { Bed transport coeff., } \mathrm{kl},(0.59 \text { if } \\
\mathrm{kl}\end{array}$ & $\begin{array}{l}\mathrm{V} * / \mathrm{W}<0.5 \\
0.69\end{array}$ & $\begin{array}{l}0.64 \text { if } \\
0.69\end{array}$ & $\begin{array}{l}.5<V^{*} / \mathrm{w}<2 \\
0\end{array}$ & ; 0.69 if & $\mathrm{V} * / \mathrm{w}>2$. & $0 \mathrm{p} .33)$ \\
\hline $\mathrm{y}^{2}$, depth in contraction, ft & 12.29 & 15.60 & $\mathrm{ERR}$ & & & \\
\hline ys, scour depth, ft (y2-y_bridge) & 0.38 & 3.11 & $\mathrm{~N} / \mathrm{A}$ & & & \\
\hline
\end{tabular}

Pressure Flow Scour (contraction scour for orifice flow conditions)

Chang pressure flow equation $\quad \mathrm{Hb}+\mathrm{Ys}=\mathrm{Cq} * \mathrm{qbr} / \mathrm{VC}$

$\mathrm{Cq}=1 / \mathrm{Cf} * \mathrm{CC} \quad \mathrm{Cf}=1.5 * \mathrm{Fr}^{\wedge} 0.43(<=1) \quad \mathrm{CC}=\operatorname{SQRT}[0.10(\mathrm{Hb} /(\mathrm{ya}-\mathrm{w})-0.56)]+0.79 \quad(<=1)$

Umbrell pressure flow equation

$(\mathrm{Hb}+\mathrm{Ys}) / \mathrm{ya}=1.1021 *[(1-\mathrm{w} / \mathrm{ya}) *(\mathrm{Va} / \mathrm{VC})] \wedge 0.6031$

(Richardson and other, 1995, p. 144-146)

Q, total, cfs

Q100

$Q$, thru bridge $M C$, cfs

3310

3310

1.04

Vc, critical velocity, ft/s

$\mathrm{Va}$, velocity MC approach, ft/s

Main channel width (normal), ft

4.16

58.6

Cum. width of piers in MC, ft

0.0

W, adjusted width, ft

qbr, unit discharge, ft2/s

Area of full opening, ft2

$\mathrm{Hb}$, depth of full opening, ft

$\begin{array}{lll}58.6 & 58.6 & 0.0\end{array}$

$56.5 \quad 81.1 \quad$ ERR

$698.0 \quad 732.0 \quad 0.0$

Fr, Froude number, bridge MC

11.91

12.49

ERR

0

$\begin{array}{lll}11.91 & 12.49 & \\ 0 & 0.33 & 0\end{array}$

OtherQ

0

$\mathrm{N} / \mathrm{A}$

$\mathrm{N} / \mathrm{A}$

$\mathrm{N} / \mathrm{A}$

0.0

0

.0 


\begin{tabular}{|c|c|c|c|}
\hline Cf, Fr correction factor $(<=1.0)$ & 0.00 & 0.93 & 0.00 \\
\hline **Area at downstream face, ft2 & $\mathrm{N} / \mathrm{A}$ & $\mathrm{N} / \mathrm{A}$ & $\mathrm{N} / \mathrm{A}$ \\
\hline **Hb, depth at downstream face, ft & $\mathrm{N} / \mathrm{A}$ & $\mathrm{N} / \mathrm{A}$ & ERR \\
\hline **Fr, Froude number at DS face & ERR & ERR & ERR \\
\hline${ }^{*} \mathrm{Cf}$, for downstream face $(<=1.0)$ & $\mathrm{N} / \mathrm{A}$ & $\mathrm{N} / \mathrm{A}$ & $\mathrm{N} / \mathrm{A}$ \\
\hline Elevation of Low Steel, ft & 0 & 498.53 & 0 \\
\hline Elevation of Bed, ft & $\mathrm{N} / \mathrm{A}$ & 486.04 & $\mathrm{~N} / \mathrm{A}$ \\
\hline Elevation of Approach, ft & 0 & 499.36 & 0 \\
\hline Friction loss, approach, ft & 0 & 0.07 & 0 \\
\hline Elevation of WS immediately US, ft & 0.00 & 499.29 & 0.00 \\
\hline ya, depth immediately US, ft & $\mathrm{N} / \mathrm{A}$ & 13.25 & $\mathrm{~N} / \mathrm{A}$ \\
\hline Mean elevation of deck, ft & 0 & 510 & 0 \\
\hline w, depth of overflow, ft $(>=0)$ & 0.00 & 0.00 & 0.00 \\
\hline 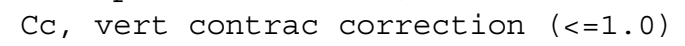 & ERR & 0.99 & ERR \\
\hline$* * \mathrm{Cc}$, for downstream face $(<=1.0)$ & ERR & ERR & $\mathrm{ERR}$ \\
\hline Ys, scour w/Chang equation, ft & $\mathrm{N} / \mathrm{A}$ & 69.86 & $\mathrm{~N} / \mathrm{A}$ \\
\hline $\begin{array}{l}\text { Ys, scour w/Umbrell equation, ft } \\
\text { Armoring }\end{array}$ & $\mathrm{N} / \mathrm{A}$ & 22.88 & $\mathrm{~N} / \mathrm{A}$ \\
\hline \multicolumn{4}{|c|}{$\begin{array}{l}\text { Armoring } \\
\text { Dc }=\left[\left(1.94 * \mathrm{~V}^{\wedge} 2\right) /(5.75 * \log (12.27 * \mathrm{y} / \mathrm{D} 90))^{\wedge} 2\right] /[0.03 *(165-62.4)] \\
\text { Depth to Armoring }=3 *(1 / \mathrm{PC}-1) \\
\text { (Federal Highway Administration, 1993) }\end{array}$} \\
\hline Downstream bridge face property & $100-\mathrm{yr}$ & $500-y r$ & Other Q \\
\hline Q, discharge thru bridge $M C$, cfs & 3310 & 4750 & $\mathrm{~N} / \mathrm{A}$ \\
\hline Main channel area (DS), ft2 & 698 & 732 & 0 \\
\hline Main channel width (normal), ft & 58.6 & 58.6 & 0.0 \\
\hline Cum. width of piers, ft & 0.0 & 0.0 & 0.0 \\
\hline Adj. main channel width, ft & 58.6 & 58.6 & 0.0 \\
\hline D90, ft & 0.0008 & 0.0008 & 0.0000 \\
\hline D95, ft & 0.0012 & 0.0012 & 0.0000 \\
\hline Dc, critical grain size, ft & 0.0154 & 0.0285 & ERR \\
\hline Pc, Decimal percent coarser than DC & 0.000 & 0.000 & 0.000 \\
\hline Depth to armoring, ft & $\mathrm{N} / \mathrm{A}$ & $\mathrm{N} / \mathrm{A}$ & ERR \\
\hline
\end{tabular}

Abutment Scour

Froehlich's Abutment Scour

$\mathrm{Ys} / \mathrm{Y} 1=2.27 * \mathrm{~K} 1 * \mathrm{~K} 2 *\left(\mathrm{a}^{\prime} / \mathrm{Y} 1\right)^{\wedge} 0.43 * \mathrm{Fr} 1^{\wedge} 0.61+1$

(Richardson and others, 1995, p. 48, eq. 28)

\begin{tabular}{|c|c|c|c|c|c|c|}
\hline \multirow[b]{2}{*}{ Characteristic } & \multicolumn{2}{|c|}{ Left Abutment } & \multicolumn{4}{|c|}{ Right Abutment } \\
\hline & $100 \mathrm{yr}$ & $500 \mathrm{yr}$ & Dther Q & $100 \mathrm{yr}$ & 0 yr & Cher $\mathrm{Q}$ \\
\hline (Qt), total discharge, cfs & 3310 & 4750 & 0 & 3310 & 4750 & 0 \\
\hline a', abut.length blocking flow, ft & 38.3 & 59 & 0 & 67.5 & 97 & 0 \\
\hline Ae, area of blocked flow ft2 & 86.7 & 175 & 0 & 173 & 325 & 0 \\
\hline Qe, discharge blocked abut., cfs & 162 & 388 & 0 & 385 & 778 & 0 \\
\hline (If using Qtotal_overbank to o & & ve o & 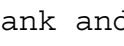 & ter & & \\
\hline Ve, $(\mathrm{Qe} / \mathrm{Ae}), \mathrm{ft} / \mathrm{s}$ & 1.87 & 2.22 & ERR & 2.23 & 2.39 & ERR \\
\hline
\end{tabular}




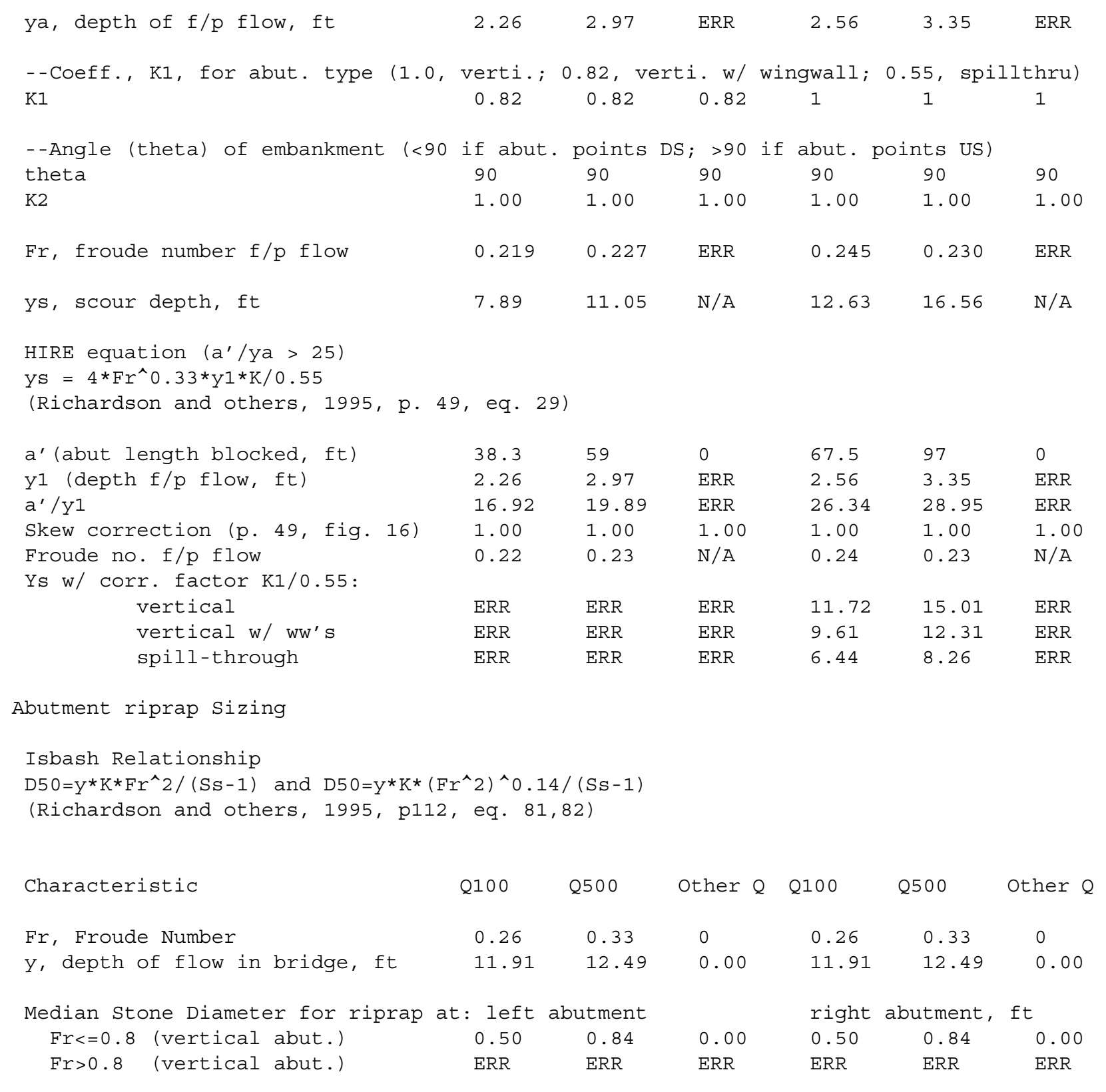


